\title{
Geomorphologic context and proposed chronostratigraphic position of Lower Palaeolithic artefacts from the $0 p$ de Schans pit near Kesselt (Belgium) to the west of Maastricht
}

\author{
E.P.M. Meijs ${ }^{1,{ }^{*}}$, Ph. van Peer $^{2}$ \& J.P.L.M.N. de Warrimont ${ }^{3}$ \\ 1 ArcheoGeolab, Veulenerbank 33, NL-6213 JR Maastricht, the Netherlands. \\ 2 Prehistoric Archaeology Unit, Katholieke Universiteit Leuven, P0 Box 2409, BE-3001 Heverlee, Belgium. \\ 3 Archeologische Vereniging Limburg, Pastoor Stassenstraat 9, NL-6243 BW Geulle, the Netherlands. \\ * Corresponding author. Email: meijs@archeogeolab.nl.
}

Manuscript received: August 2011, accepted: March 2012

\begin{abstract}
In July 2007 an important archaeological find was made in the 0p de Schans loess pit near Kesselt (Belgian Limburg) immediately to the west of the Dutch city of Maastricht. During an archaeological rescue dig, three Lower Palaeolithic artefacts were recovered from the infill of an ancient erosion gully: a bifacial side-scraper, an atypical biface and a cortical flake. Typologically, the artefacts can be classified as Acheulean. In this region, harbouring several such brickyard pits, these are the oldest artefacts yet found, prompting further investigations into the stratigraphic position of the archaeological layer. The 0p de Schans pit, which has yielded several Middle Palaeolithic occupation horizons, is located in the middle of an ancient sediment trap. Because of this exceptional geomorphologic situation, multiple ancient sediments have been preserved which elsewhere were entirely removed during subsequent erosion phases. Here five separate loess beds with intercalated interglacial palaeosols are present, overlying the deposits of the River Maas (Meuse). This sequence has been used as a hypothetical framework for elaborating a chronostratigraphic model. The archaeological level in question, discovered at the base of a subsequently infilled erosion gully, can most likely be chronostratigraphically dated to around the start of Marine Isotope Stage 10 (MIS 10), in the era of the Pottenberg discordance (approx. 390 ka). However, the possibility cannot be excluded that the gully in which the artefacts were found dates from an early phase of MIS 12 (approx. 480 ka). The age may in fact be greater still, as the artefacts have been eroded out of their original, primary context and subsequently deposited in the gully. Hypothetically, they may even have been taken up from the Maas loam of the Kesselt Maas terrace (MIS 13) that here is situated directly below the archaeological horizon. This would make the maximum age of the artefacts recovered from the gully around $500 \mathrm{ka}$.
\end{abstract}

Keywords: Acheulean, archaeology, loess stratigraphy, Meuse basin, river terraces

\section{Introduction}

The 0p de Schans loess pit is located in Kesselt (Belgian Limburg), just east of the Albert Canal near the Dutch city of Maastricht (Fig. 1). Here the European loess belt is a mere $30 \mathrm{~km}$ wide, hemmed in between the sands of the Campine area to the north and the Palaeozoic basement rocks of the Ardennes to the south. The pit is located in the middle of an ancient sediment trap between the upland areas of Dousberg to the north-east and Riemst to the south-west (Fig. 2). Because of this exceptional palaeo-geomorphological situation, in this area numerous ancient sediments have been preserved that elsewhere were entirely removed during erosional phases (Figs 2 and 3). In places, the total thickness of the loam strata in this region can be as much as 20 metres. In the (recent) past a considerable amount of archaeological and geological research has been conducted here, both in nearby pits, including those of Romont, Kesselt, Veldwezelt and Belvédère, and during the widening of the Albert Canal between 1970 and 1984 (Fig. 1). The work of Jef Vandenberghe in the 1980s in the Belvédère pit (Vandenberghe, 1993; Vandenberghe et al., 1993) and in the 1990s in the Kesselt pit (Vandenberghe et al., 1998) provided major impetus for further studies in this area. 
The first Late Pleistocene archaeological finds in the $0 p$ de Schans pit were made in 2001 (level 1-north, Fig. 3, Table 1). The artefacts from this horizon were recovered from a primary
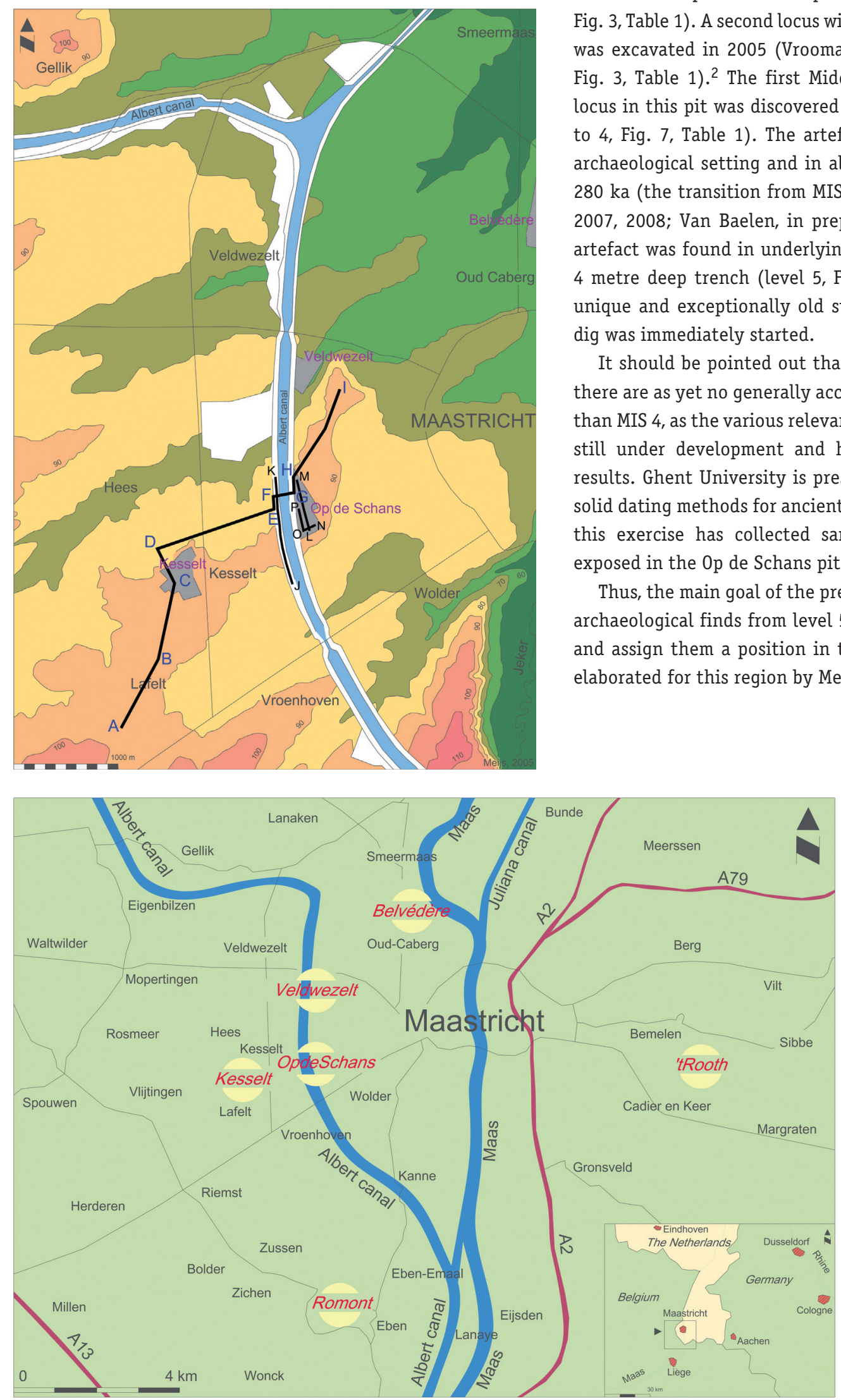

(i.e. original) archaeological context, some of which could be successfully refitted. ${ }^{1}$ Systematic prospecting between 2001 and 2006 yielded multiple further Late Pleistocene finds in several other parts of the $0 p$ de Schans loess pit (levels 1-2, Fig. 3, Table 1). A second locus with Middle Palaeolithic artefacts was excavated in 2005 (Vroomans et al., 2006; level 1-south, Fig. 3, Table 1). ${ }^{2}$ The first Middle Pleistocene archaeological locus in this pit was discovered in 2006 (level 3, Fig. 3; 0DS 1 to 4, Fig. 7, Table 1). The artefacts were found in a primary archaeological setting and in all likelihood date from around $280 \mathrm{ka}$ (the transition from MIS 9 to MIS 8; Van Baelen et al., 2007, 2008; Van Baelen, in preparation). In addition a lithic artefact was found in underlying sediment from the base of a 4 metre deep trench (level 5, Fig. 3, Table 1). Because of its unique and exceptionally old stratigraphic position, a rescue dig was immediately started.

It should be pointed out that for these kinds of sediments there are as yet no generally accepted chronological data older than MIS 4, as the various relevant absolute dating methods are still under development and have not yet yielded reliable results. Ghent University is presently engaged in research on solid dating methods for ancient loess sediments and as part of this exercise has collected samples of all the loess strata exposed in the 0p de Schans pit (Van de Moortel, 2008).

Thus, the main goal of the present paper is to put the oldest archaeological finds from level 5 in a geomorphologic context and assign them a position in the chronostratigraphic model elaborated for this region by Meijs (2002). 


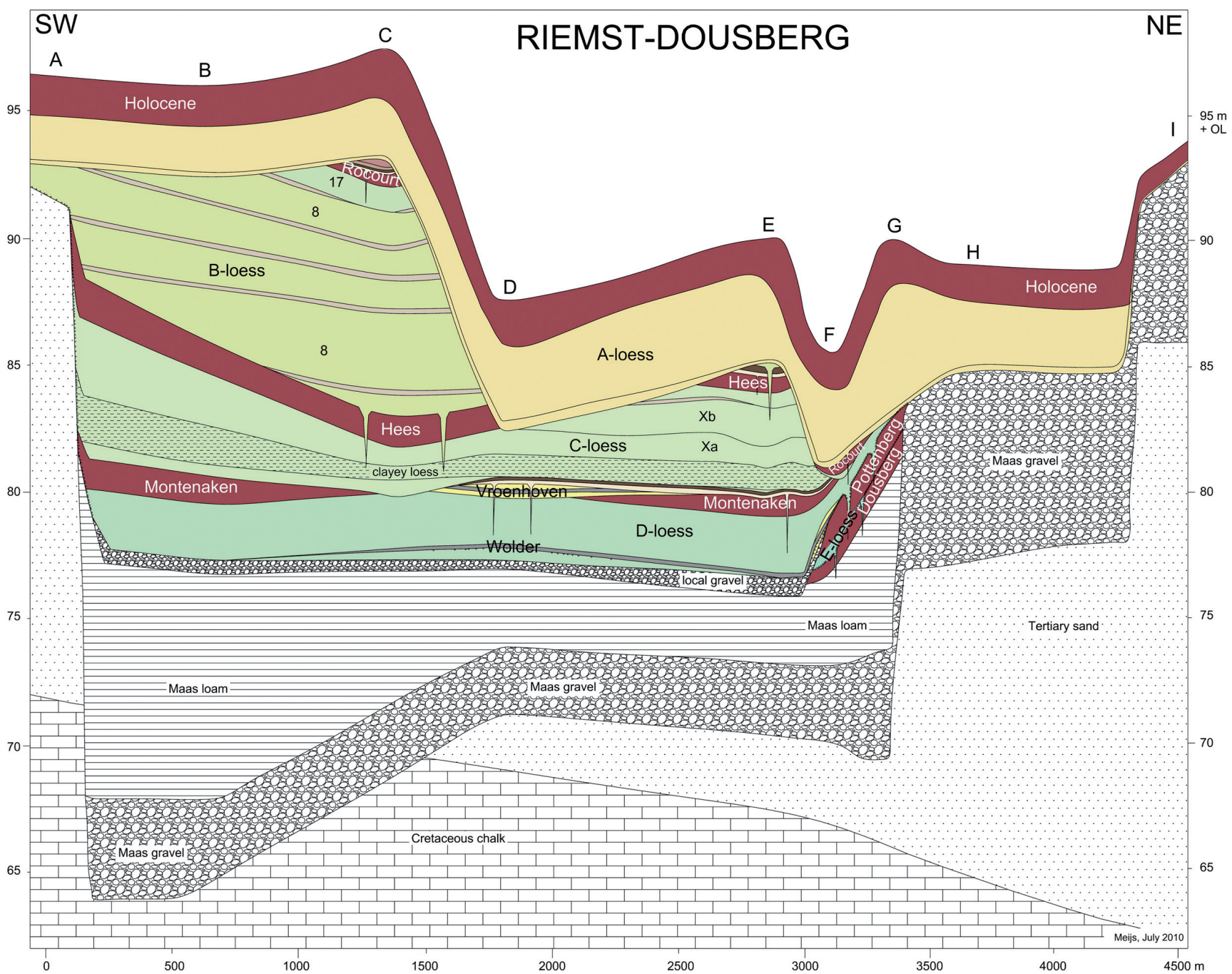

Fig. 2. Composite cross-section, connecting drillings A-B and studied profile C-I between the upland areas of Riemst in the south-west and Dousberg in the north-east. Brown units are luvisolic palaeosol horizons (for profile location, see Fig. 1).

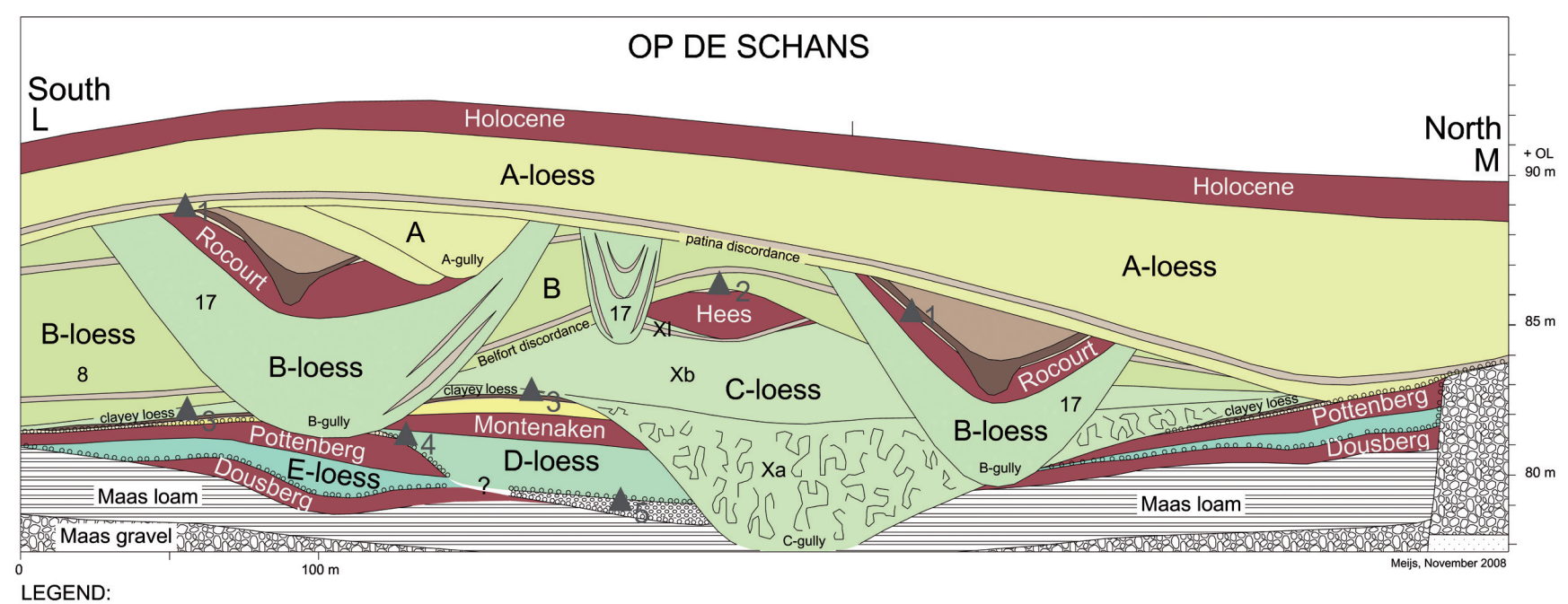
$\Lambda_{1}$ archaeological level 1: $80 \mathrm{ka}$
$\Delta_{2}^{1}$ archaeological level 2: $200 \mathrm{ka}$ ( slightly reworked)
$\Delta_{3}$ archaeological level 3: $280 \mathrm{ka}$
$\Delta_{4}$ archaeological level 4: 390 ka or older (reworked)
$\Lambda_{5}^{4}$ archaeological level 5: 390 / 480 ka or older (reworked)

Fig. 3. Sediments, palaeosols and archaeological horizons in the Op de Schans pit, showing the position of the oldest artefacts yet found, level 5 (for location of profile L-M, see Fig. 1). 


\section{Lithostratigraphy of the region}

\section{Maas sediments}

In the geomorphology of this region the River Maas (Meuse) plays a pivotal role. The Maas sedimentation record has been reconstructed on the basis of data obtained during construction (and subsequent widening) of the Albert Canal and from borings in the context of loess quarrying. Overlying the calcareous members of the Cretaceous and Palaeocene and the thick sandy Tertiary strata, the Maas deposited an essentially uniform bed of gravel over a wide area just prior to the Brunhes-Matuyama palaeomagnetic reversal. This is known as the Pietersberg-2 terrace level (Van den Berg, 1996; Fig. 4). In a two-stage process this level was subsequently incised, creating the Dousberg and Hazendans terraces (Table 2; Fig. 4). The Maas then formed a meander around a promontory in the palaeolandscape, creating the so-called Kesselt terrace level (Table 2; Fig. 4). From this relatively small meander the Maas would then appear to have shifted further in a southwesterly direction, forming the Vroenhoven terrace level (Table 2; Fig. 4). In the process of constructing the Vroenhoven terrace the Maas removed major quantities of Tertiary sand. Subsequently, the river formed another three, deeper-lying terraces in the region: the Belvédère terrace (Table 2; Fig. 4), the Eisden-Lanklaar/Gronsveld terrace and the Maasmechelen/Maarland terrace (Felder \& Bosch, 1989; Van den Berg, 1996; Table 2). On the high-altitude river terraces of Pietersberg, Dousberg and Hazendans interglacial palaeosols have never been found. Here the Maas gravels are generally overlain by a thin cover of Weichselian loess. Because the former Kesselt and Vroenhoven Maas carried large volumes of Tertiary sand, the fine-grained 'Maas loam' (overbank sediment) is often sandy in these terraces. At various levels this Maas loam contains veneers of gravel with occasional, isolated Maas boulders up to $60 \mathrm{~cm}$ in diameter. These were probably brought in on ice rafts from upstream regions during the springtime thaw.

\section{Loess sediments}

In the sediment trap environment of this region, Maas sediments can be overlain by five separate loess beds intercalated with luvisols (Fig. 2, 3, 5, 7 and 8). A composite sequence shows the lithological, cryogenic, faunal and pedological phenomena present in the different loess pits of this area and along the Albert Canal (Fig. 5).

According to a stratigraphic revision by Juvigné et al. (1996), interglacial soil formation was demonstrated by micromorphological research for the Rocourt, Hees and Montenaken luvisols

Fig. 4. Terraces of the River Maas in the study area. In blue: elevation of gravel base in metres above Ostend Level; dotted areas represent probable relic river meander bends (after Halet, 1932; Felder \& Bosch, 1989; Geolab, 1996; Meijs, 2002).

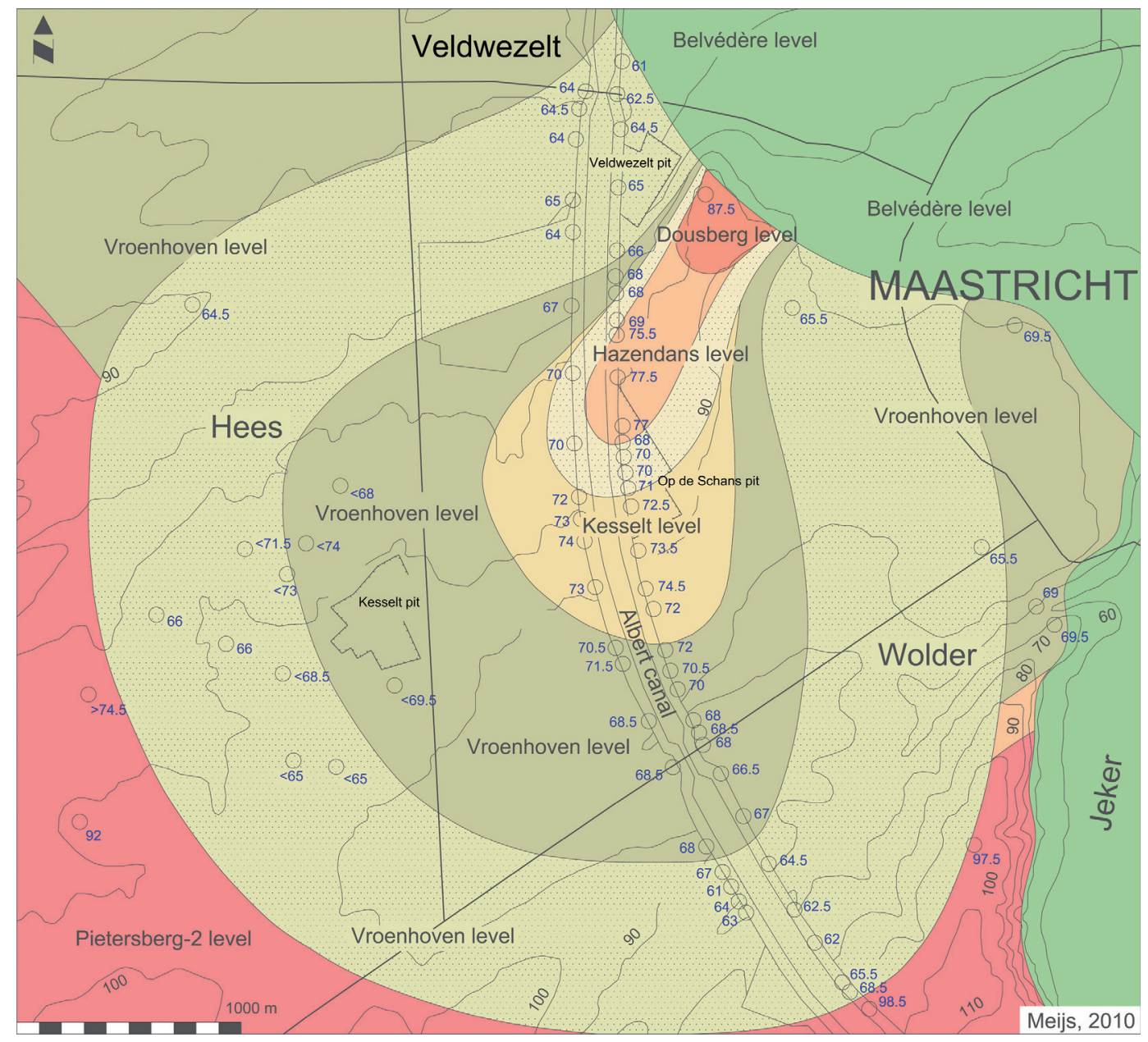




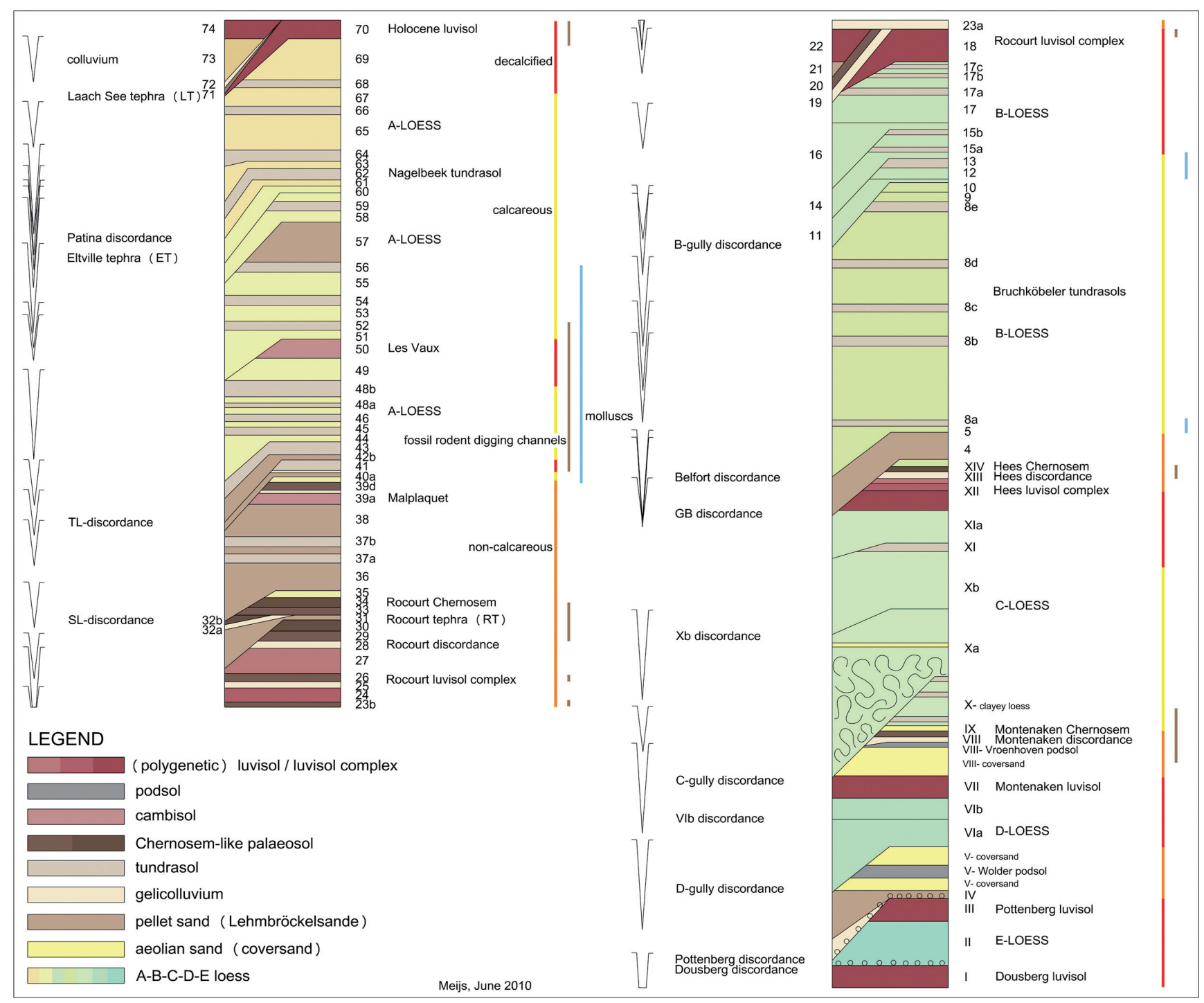

Fig. 5. Composite profile, showing the complete regional loess sequence, based on data from multiple locations along the Albert Canal and surrounding loess pits (after Felder \& Bosch 1988; Meijs, 2002, 2006, 2011). To the left of the lithological column the different fossil ice-wedge generations are shown and to the right the carbonate content and the presence of fossil rodent digging channels (brown bar) and molluscs (blue bar).

(Mees, 1984). The Pottenberg and Dousberg luvisols have only been studied macroscopically, but here too an interglacial origin is indicated by strong brown to red soil weathering and clearly visible non-humical clay cutans. The nomenclature of the units is after Felder \& Bosch (1988) and Meijs $(2002,2006,2011)$.

At various places in this region a brown luvisol has been found on top of the Kesselt Maas loam, the so-called Dousberg soil (unit I, Fig. 5).

\section{E-loess}

Subsequently, pronounced erosion truncated the Dousberg palaeosol during the transition to the following glacial (Dousberg discordance), accompanied by fossil ice wedge casts and substantial amounts of gravel (Lauwers \& Meijs, 1985; Felder \& Bosch, 1988; Meijs 2002). During this period the Maas formed the deeper Vroenhoven terrace, with an incision depth of around
64 metres above 0stend Level (OL). The maximum difference in height between the upland-covering Dousberg luvisol or the surface of the Kesselt Maas loam (at $82 \mathrm{~m}+0 \mathrm{~L}$ on average) and the base of the Vroenhoven terrace (at approx. $64 \mathrm{~m}+0 \mathrm{~L}$ ) was then around 18 metres. During this erosion phase, channels will inevitably have been carved out in the palaeolandscape. The area in which the Dousberg soil has been preserved is so small, though, that reliable reconstruction of drainage patterns has proved impossible. However, overall drainage in a westerly direction has been assumed on the basis of the lower position of the Dousberg discordance just west of the 0p de Schans pit (along the Albert Canal). On top of the Dousberg discordance a deposit of sandy loess is present with scattered lenses of aeolian coversand (E-loess). This E-loess was deposited around the same time as the gravel aggradation phase of the Vroenhoven terrace level. 
The relatively large amount of aeolian coversand and sandy loess sediments in this E-loess derives in part from the Tertiary sand in the surrounding region and the sandy local Maas deposits.

On top of the Vroenhoven Maas loam and in upland portions of outcropping E-loess a very well-developed, purplish-red marbled luvisol was formed, the so-called Pottenberg soil (unit III, Fig. 5). This is by far the strongest and most pronounced luvisol present in the area. In the field it is a characteristic marker horizon, showing a compact, purplish-red marbled appearance and an abundance of non-humical clay cutans.

\section{$D$-loess}

This period of soil formation was followed by a pronounced erosion phase with substantial gravel deposition: the Pottenberg discordance (unit IV; Fig. 5 and 6). Several large Maas boulders in this gravel, measuring up to $60 \mathrm{~cm}$, probably derive from the underlying Maas loam, which at the time outcropped higher in the landscape (Fig. 8). In the 0p de Schans pit several redeposited artefacts have been recovered from this erosion layer (level 4, Fig. 7; Van Baelen, in preparation). During this phase, erosion channels formed, sometimes in the shape of wider depressions, with pronounced denudation of the palaeolandscape (Fig. 6).
These channels and depressions have a basal layer of gravel, made up of eroded Maas gravel as well as gravel from local Tertiary strata, and are overlain by reworked sands with occasional veneers of gravel. In all probability the $0 p$ de Schans pit is traversed by such a shallow erosion gully, in which basal infill the artefacts were found that are the main interest of this paper (level 5, Fig. 3). However, theoretically this could also represent a channel dating back to the erosional phase of the Dousberg discordance. Unfortunately, owing to field conditions, the sediment profile that might have provided conclusive evidence on this issue could not be uncovered (indicated by a question mark in Fig. 3). Everywhere else in the study area, however, the channels formed during the Pottenberg erosion phase down-cut deeper than those formed in the period of the Dousberg discordance, making it likely that the gully forming the provenance of the oldest artefacts yet found is of a similar age as the Pottenberg discordance. These erosion channels have generally cleared both the Pottenberg and Dousberg palaeosol in their entirety (Fig. 8). Since in the 0p de Schans pit we are concerned with an incipient, shallow gully, it was probably infilled fairly quickly, after which the sequence continued with aeolian deposition of homogeneous sandy D-loess. Contemporaneously with the infilling of these erosion channels and depressions, coversands were deposited in the

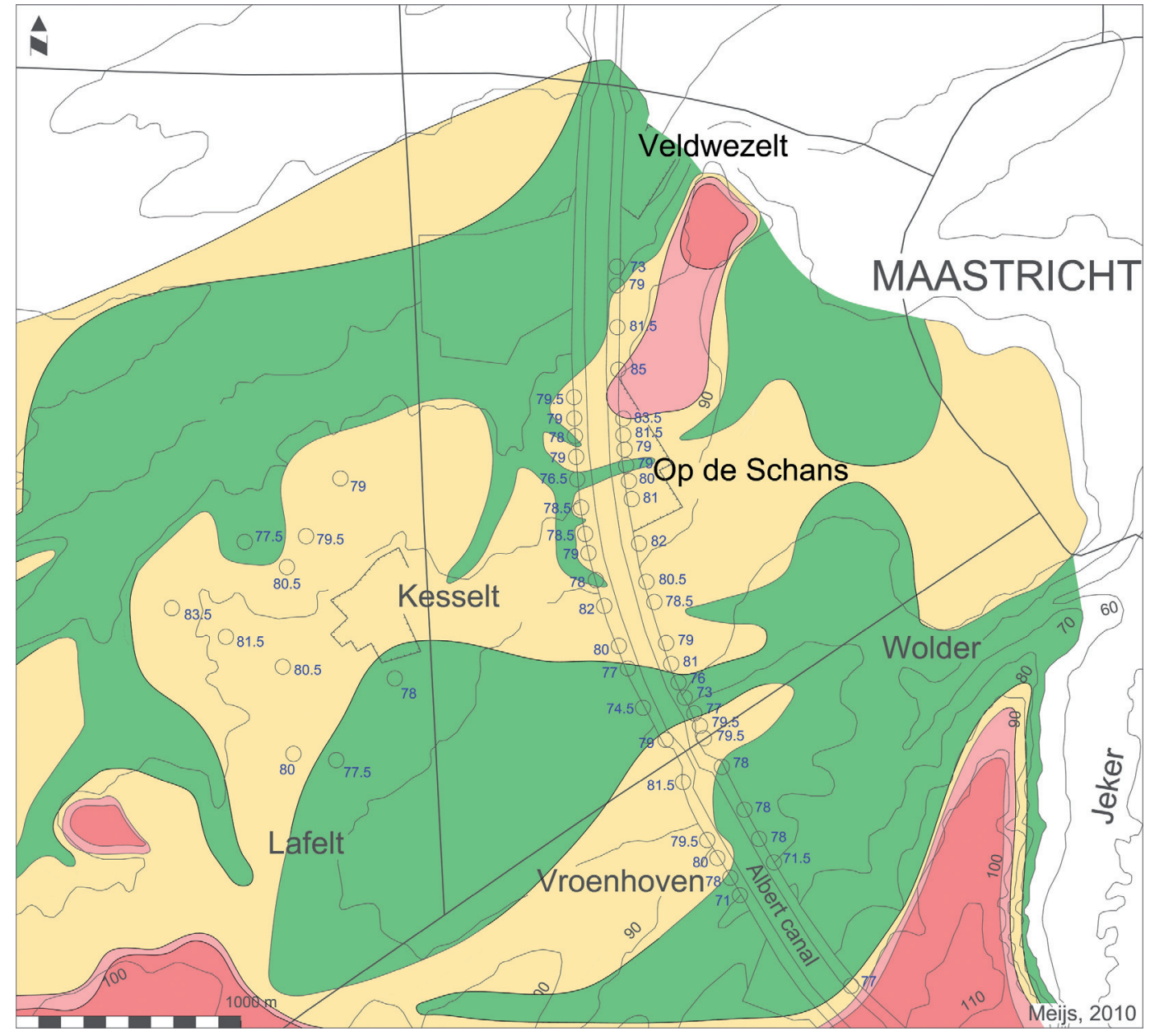

Fig. 6. Drainage patterns during the erosion phase of the Pottenberg discordance. In blue: elevation of its erosion base in metres above Ostend Level. 


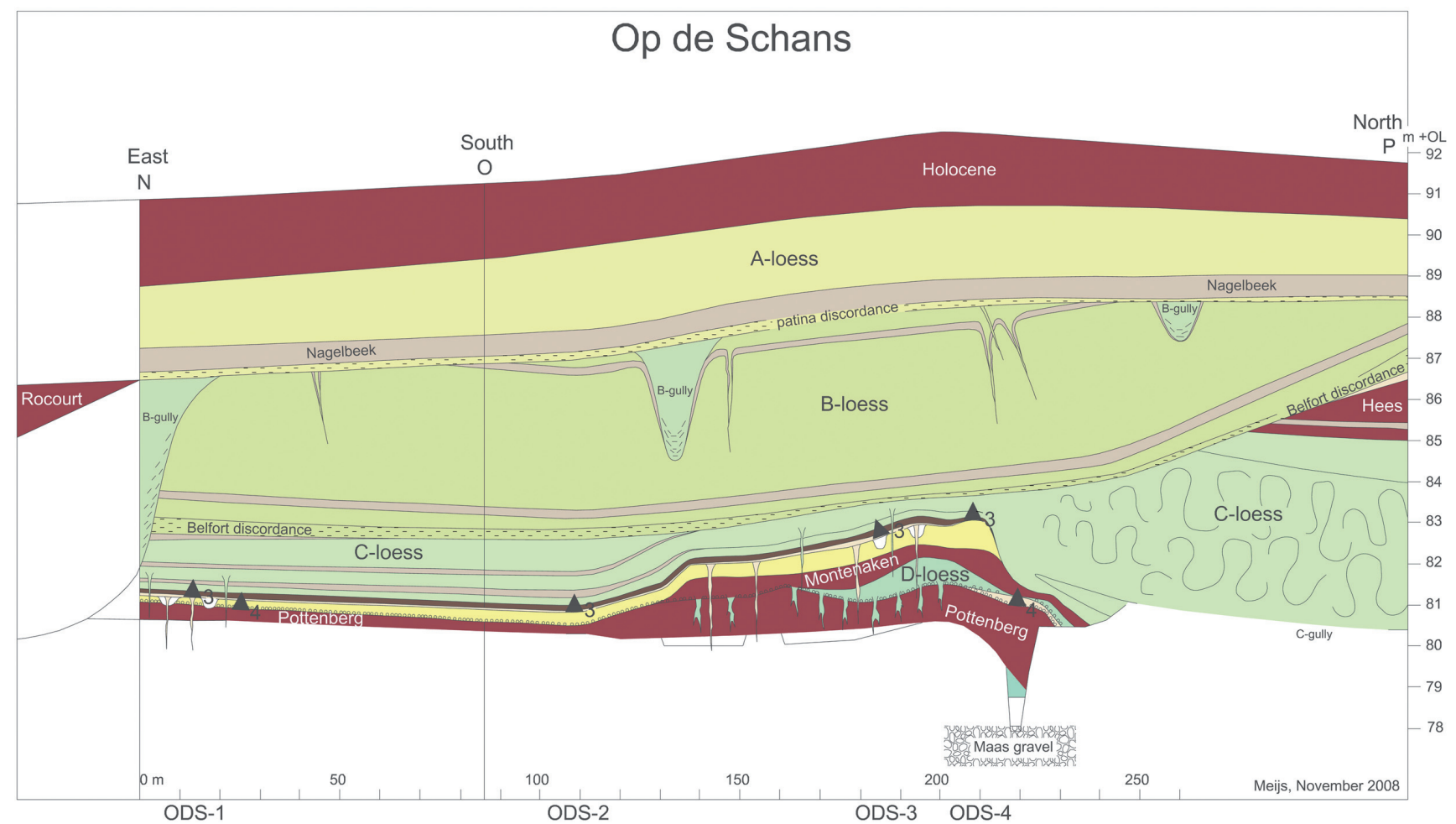

Fig. 7. Profile N-O-P from the western part of the Op de Schans pit, with two archaeological loci in the Pottenberg discordance (level 4; Van Baelen, in preparation) and four archaeological loci just below the humic palaeosol (level 3, ODS 1-4; Van Baelen, in preparation). For location of profile N-O-P, see Fig. 1.

upland areas. This was followed by a period of soil formation in which the so-called Wolder podsol was formed, with on top a dark grey band, underlain by a white, bleached layer and deeper still a ferruginous illuvial horizon (Felder \& Bosch, 1988; unit V, Fig. 5). Prior to this podsol pedogenesis there had been erosion, witness a thin veneer of gravel just beneath the podsol. Scattered charcoal fragments are present in the dark grey humic zone of the podsol. It also shows pronounced cryoturbation features. Particularly on the margins towards uphill areas, the Wolder podsol is overlain by coversands. In the gullies and larger drainage depressions, upward the sequence continues with a stratified grey-green to yellowish sandy loam, while in higher parts of the palaeolandscape aeolian homogeneous sandy loess was deposited (D-loess). The latter situation concerned the previously infilled gully traversing the $0 \mathrm{p}$ de Schans pit where greyish homogeneous D-loess covers the gully infill with the oldest, level 5 artefacts (Fig. 3). Extending deep down from the base of this D-loess broad ice-wedge casts are present (Fig. 7;

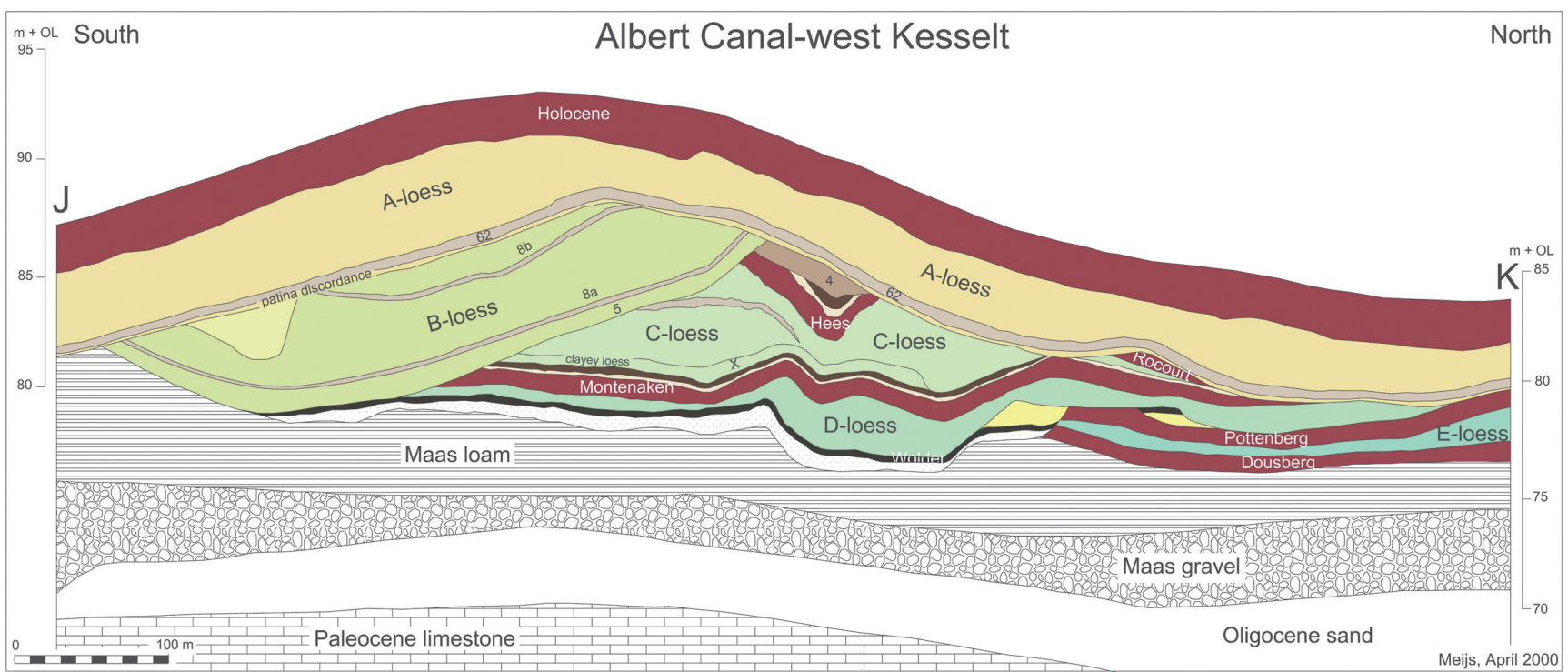

Fig. 8. Profile along the west side of the widened Albert Canal near Kesselt. In the middle a wide erosion gully removed major portions of the Pottenberg and Dousberg soils during the so-called Pottenberg discordance (for location of profile J-K, see Fig. 1). 
depth: $125 \mathrm{~cm}$, width: $25 \mathrm{~cm}$ ). These are filled with the aforementioned sandy homogeneous D-loess, which at the time will have formed a sediment blanket over the area. Soon after deposition, however, much of this D-loess was probably removed, as it is overlain by a strongly reworked sediment in which sandy loams and yellow sands alternate, with scattered sediment lenses rich in sesquioxides.

Once again, the marked presence of aeolian coversands and sandy loess sediments during this period can be explained partly by the presence of Tertiary sands in the surrounding area and sandy Maas sediments in the local vicinity. Only in periods of most vigorous loess influx will homogeneous sandy loess have been deposited.

Next, a red brown luvisol (Montenaken soil) developed in outcropping sandy E/D loess deposits, while in others parts of the palaeolandscape it overprinted the existing Pottenberg soil (Mees, 1984; Felder \& Bosch, 1988; Meijs, 2002; unit VII, Fig. 5).

\section{C-loess}

In some places this luvisol was eroded by wind and covered by a metre of yellowish white aeolian coversand. In this coversand the Vroenhoven podsol later developed, to be subsequently buried by a following layer of coversand. Because the Tertiary sands and sandy Maas sediments were still often exposed, the area was vulnerable to sand drift and deposition of coversand. Several small ice-wedge casts protrude down from the topmost dark grey horizon of the podsol (depth: $75 \mathrm{~cm}$, width: $3 \mathrm{~cm}$ ). It is strongly convoluted by cryoturbation and contains scattered charcoal fragments. In most places this coversand complex was then severely eroded (Fig. 5, Montenaken discordance). From this discordance (comprising small 2-3 cm gravels, sesquioxides and charcoal fragments), ice-wedge casts extend deep into the underlying sediment (depth: $250 \mathrm{~cm}$, width: $25 \mathrm{~cm}$ ). Downwards these casts soon become narrower (Fig. 7). In the 0p de Schans pit four concentrations of artefacts were recovered in a primary archaeological context directly above this erosion horizon (level 3; ODS 1-4 in Fig. 7; Van Baelen, in preparation). On top of this archaeological level sandy loess is present and sometimes even a layer of pure coversand that gradually develops into a humic zone (unit IX, Fig. 5; Chernosem). During this period burrowing animals were very active in the subsoil, as evidenced by numerous infilled burrows, known as 'krotovinas' (diameter $10 \mathrm{~cm}$ ). After a brief continuation of sandy loess deposition followed a period in which homogeneous clayey loess was deposited, while the burrowing activity continued for a time. This clayey loess is very characteristic and often shows weak tundrasol development in its lower and upper part (unit X, Fig. 5). Extending down from the middle of this clayey loess bed isolated ice-wedge casts are present (depth: $125 \mathrm{~cm}$, width: $10 \mathrm{~cm}$ ). During this 'clayey loess period', for the first time the entire area was covered with homogeneous, non-sandy loess. Less clayey loess which is capped by a weak tundrasol overlies this sediment. Next, deep erosion gullies were formed under cold permafrost conditions (Fig. 3, 7 and 9). This erosion unconformity has been termed the 'C-gully discordance' (Fig. 5). In contrast to earlier periods, however, much of the palaeolandscape remained covered with a blanket of clayey loess. Again in contrast to preceding periods, the bottom of the erosion channels is not characterised by a basal gravel layer, but by sesquioxide-rich grit with an occasional 2-3 cm gravel. Along the margins of the erosion channels pronounced gelifluction can be observed as well as a creepaffected relic ice-wedge polygon network (depth: $200 \mathrm{~cm}$, width: $25 \mathrm{~cm}$ ). These low-lying parts of the palaeolandscape were then infilled with stratified 'sands and silts', marking alternating periods of gelifluction, aeolian sand influx and loess deposition (unit Xa, Fig. 3, 5 and 7). Here, too, the loamy layers are very clayey. At the base of this stratum several generations of isolated fossil ice-wedges can be observed, while higher up the sediment is strongly convoluted by cryoturbation (amplitude: $1.5-2 \mathrm{~m}$ ). 0n top the sediment becomes more homogeneous, but there are still several conspicuous weakly cryoturbated yellow coversand lenses visible. Ultimately, the entire palaeolandscape was covered with loess. After an erosion phase (with small 1-2 cm gravels) weakly stratified, less clayey loess followed, with on top a well-developed tundrasol (unit XI, Fig. 5). At the transition to the next interglacial, deeper drainage channels were once again formed, the base of which became part-filled with gelifluction material just before the onset of the warmer period (Fig. 8).

Next a polygenetic luvisol developed in the above described sediments: the so-called Hees soil (Mees, 1984; Meijs, 2002). ${ }^{3}$ In depressions it sometimes appears as a luvisol complex, exhibiting three individual luvisols (unit XII, Fig. 5).

\section{$B$-loess}

In the early part of the following glacial the Hees soil with its overlying humic horizon were severely eroded. Extremely cold permafrost conditions were responsible for denudation of major parts of the palaeolandscape (Meijs, 2011; unit 4, Fig. 5 and 8). This so-called 'GB-discordance' cuts through a line of major ice wedge casts, filled with erosion sediment (depth: $120 \mathrm{~cm}$, width: $25 \mathrm{~cm}$ ). Only in a few depressions and sediment traps did the Hees soil survive. Here it is overlain by some two metres of stratified Lehmbröckelsande, or pellet sands (Demek \& Kukla, 1969), consisting of erosion material from palaeosols and sediments exposed in uphill parts of the palaeolandscape. These Lehmbröckelsande are rich in sesquioxides. Subsequently, wind and water erosion formed a new unconformity, known as the 'Belfort discordance' (unit 5; Fig. 3, 7, 8 and 10). From its base broad ice-wedge casts filled with erosion material penetrate into the subsoil (depth: $150 \mathrm{~cm}$, width: $30 \mathrm{~cm}$; Fig. 2). In erosion channels the sediment consists of stratified, often coarse-grained gritbed-like material formed by erosion of the 


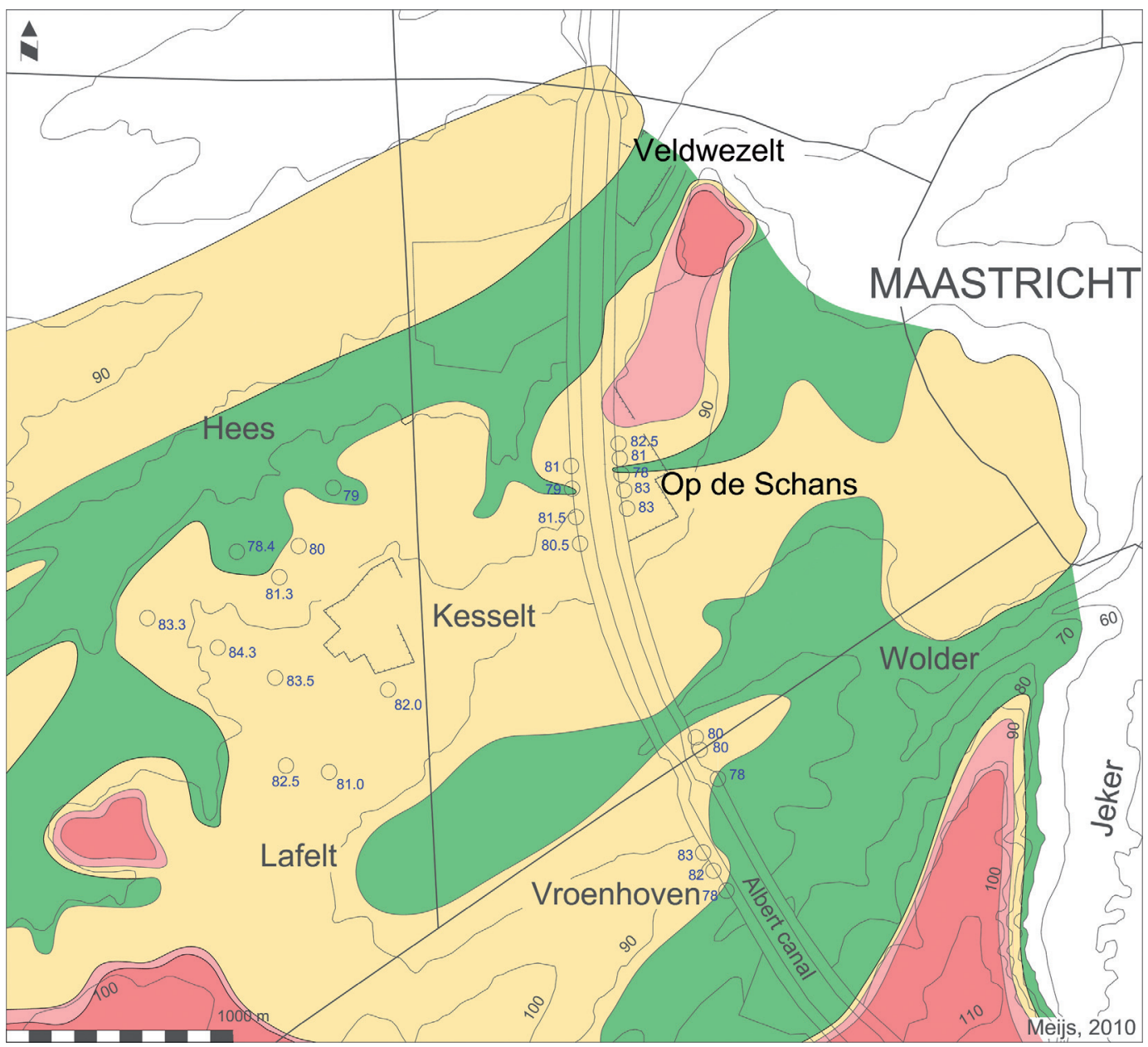

Fig. 9. Drainage patterns during the erosion phase of the 'C-gully discordance'. In blue: elevation of its erosion base in metres above Ostend Level.

hinterland under severe permafrost conditions (Meijs, 2011). At the bottom of these channels the infill shows 'cut and fill' structures, as well as dispersed blocks of sediment exhibiting highly anomalous, oblique lamination. These blocks must have arrived in a frozen state, thawing only later. This is followed by a loess complex several metres thick, exhibiting a total of five tundrasols and only weak lamination (unit 8a-8e, Fig. 2 and 5). In lowland parts of the palaeolandscape this sediment shows a strongly stratified 'sands and silts' series, with an annual influx of coversand, loess and gelicolluvium (Meijs, 2011). These tundrasols have at their top a dark grey-blue-violet colour (feebly reduced), are slightly humic and have a compact clayey structure, while their base is rusty yellow or contains dispersed rust mottles as a result of calcium and iron infiltration (Mees, 1984; Van Vliet-Lanoë, 1985; Huijzer, 1993). They contain considerably more clay and less fine sand than the overlying and underlying loess sediments (Vandenberghe et al., 1998). This appears to be an uniform phenomenon, as tundrasols from other glacial periods show similar characteristics (Antoine et al., 2009). The lower two tundrasols are particularly well developed, with an intense coloured dark yellow, $25 \mathrm{~cm}$ thick rusty zone at their base. The other, less well developed tundrasols generally show a weak, rusty yellow illuvial horizon or sparsely distributed mottles of rust. The upper parts of the compact tundrasols with their dark grey-blue-violet zones are often characterised by a whitish, calcareous band $2-5 \mathrm{~cm}$ thick, formed after the tundrasols themselves as a result of calcium precipitation during later, interglacial decalcification of the overlying sediment. Some of these whitish zones show loess nodules ('loess dolls') up to $10 \mathrm{~cm}$ in diameter. On the palaeosol surfaces of the two lowermost tundrasols micro- and macrofaunal remains were found, with lemming Dicrostonyx gulielmi (Cordy \& Udrescu, 1999) and several other species including reindeer. In the sediment sequence of unit 8 three generations of structurally reactivated cryodesiccation-related frost polygons are present (diameter: $15-25 \mathrm{~cm}$ ). In the vertical loess profile these are visible as long, indistinct frost cracks interrupted only by the formation of tundrasols $8 \mathrm{a}$ and $8 \mathrm{~b}$; the top is truncated by the Weichselian polar desert pavement of the 'patina discordance' (unit 61, Fig. 2 and 5). Three individual generations of substantial ice-wedge casts extend down from the sediment just above tundrasols $8 \mathrm{~b}, 8 \mathrm{c}$ and $8 \mathrm{~d}$ (depth: $250 \mathrm{~cm}$, width: $50-75 \mathrm{~cm}$ ). In some places these wedges follow similar courses, becoming convoluted, while elsewhere they occur separately and have been filled and truncated at three different levels. Just above and/or below these tundrasols there are sometimes horizons containing small scattered $1-2 \mathrm{~cm}$ gravels. These indicate former erosion, occurring under 


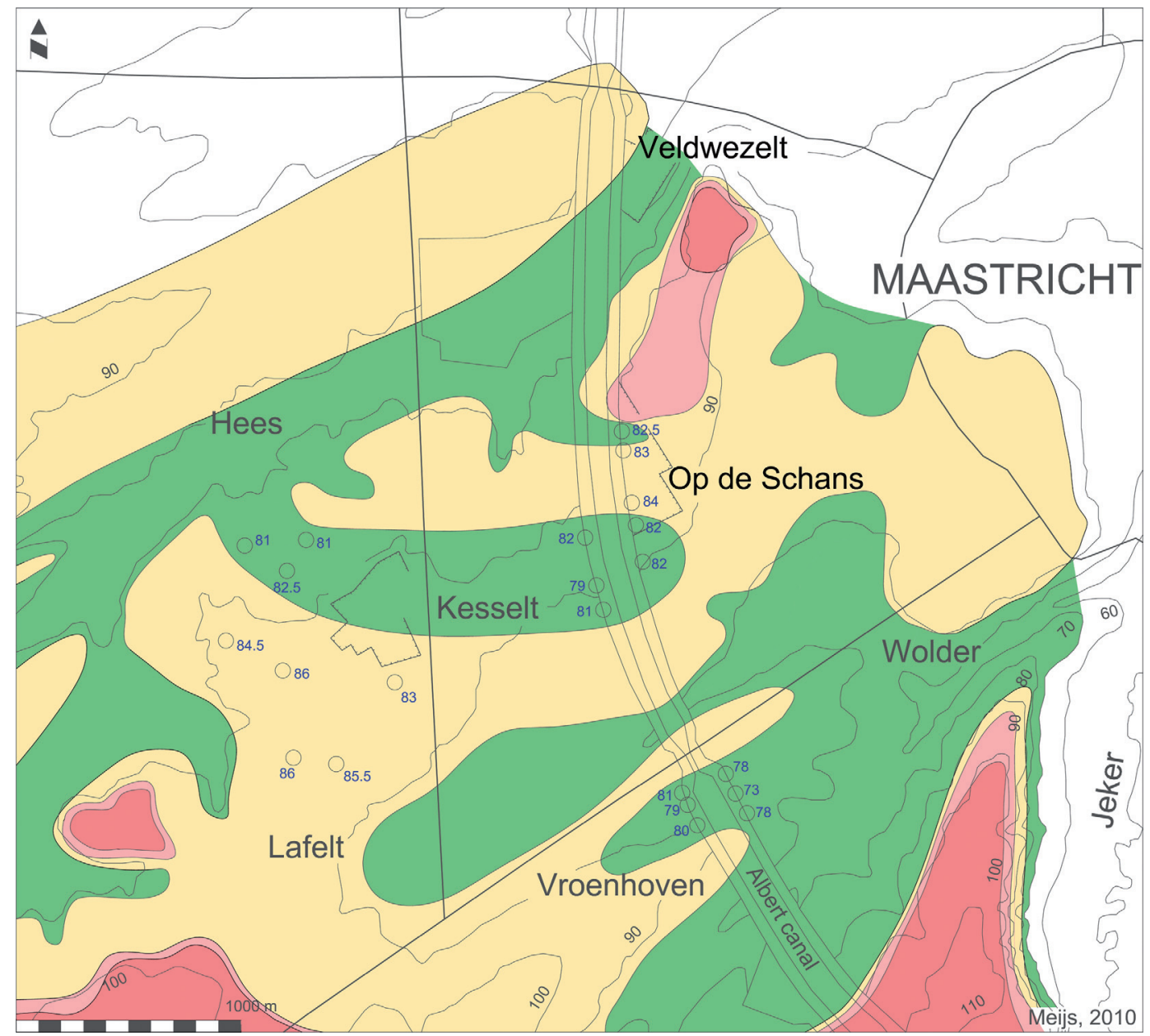

Fig. 10. Drainage patterns during the erosion phase of the Belfort discordance. In blue: elevation of its erosion base in metres above Ostend Level.

palaeoconditions that were apparently ideal for erosion, i.e. relatively humid with little vegetation cover (Antoine et al., 2009).

The aforementioned observations indicate that the loess sequence of unit 8 was deposited under extremely cold and dry permafrost conditions, with only little reworking of sediments. During tundrasol formation the climate was slightly wetter and less cold, with considerably less loess accumulation and with terrestrial molluscs becoming markedly more frequent (Moine in Antoine et al., 2009). During these periods of tundrasol formation the deposited loess was more clayey and less coarse in structure (Vandenberghe et al., 1998). Since large ice wedges can only develop during relatively humid and stable sedimentological conditions, it is assumed their growth was most pronounced in the transition phase to the more humid and less frigid tundrasol periods (Antoine et al., 2009; Meijs, 2011). After these tundrasol periods the filled ice wedges were often truncated by erosion. Downhill, these truncated ice wedge casts are sometimes overlain by geliflucted tundrasol material, been eroded from tundrasols exposed uphill. Subsequently, the climate once again became so dry that the overriding process was one of aeolian loess deposition.

At the end of this glacial period there was again widespread erosion, reflected in deep gullies partly infilled with stratified loess (Meijs 2011; 'B-gully discordance', Fig. 3, 5 and 7). In this sequence a maximum of six weak tundrasols is observed (units 11-17, Fig. 5). Here the terrestrial mollusc Arianta arbustorum could be demonstrated, in contrast to the underlying B-loess of units 5-10 (Veldwezelt pit: Kuijper, 2003; 0p de Schans and Kesselt pits: Moine, 2010). In this period the climate was indisputably wetter, but it must also have been extremely cold, because of the numerous networks of ice-wedge casts and cryoturbation horizons present in this sequence.

In the following period, a polygenetic luvisol developed in these B-loess sediments that is known as the Rocourt soil. In depressions it sometimes appears as a luvisol complex, exhibiting individual luvisols with intercalated layers of gelicolluvium (Haesaerts \& Van Vliet-Lanoë, 1973, 1981; Meijs, 2011; unit 18-27, Fig. 5).

\section{A-loess}

At the start of this glacial period the climate was alternately cold to very cold, but conditions remained fairly wet, with copious snow and/or other precipitation (Meijs, 2011; units 28-60, Fig. 5). The Rocourt tephra, containing the characteristic Enstatite minerals, is deposited just on top of the GreysemChernosem of unit 30 (Mees and Meijs, 1984; Pouclet et al., 
2008; Meijs 2011). Towards the end of the glacial the loess was deposited in an increasingly dry environment, however (Meijs, 2011; units 61-69, Fig. 5). The sequence ends with several metres of homogeneous loess (units 63-69, Fig. 5) overlying the most pronounced deflation horizon of the previous four glacial periods, the 'patina discordance' cited earlier (Meijs, 2011, unit 61, Fig. 5). This discordance represents a major and extensive wind erosion unconformity, with a polar desert pavement formed under extremely cold and dry climatic conditions. Vigorous katabathic and sublimating winds dramatically cleared the palaeolandscape in a subhorizontal manner, forming a pavement with dispersed wind-varnished gravels and artefacts (Cofflet \& Schirmer, 2002; Meijs, 2011). The lowland facies of the sediment series of unit 61-69 exhibits a stratified complex of 'sands and silts', with annual influx of coversand, loess and gelicolluvium (Meijs, 2011). The loess sequence is capped by the Holocene soil.

\section{Chronostratigraphic interpretation of the Maas and loess sequences}

\section{Introduction}

Glacial-interglacial cycles with a periodicity of around $100 \mathrm{ka}$ are indisputably reflected in the ice records of Greenland (Johnsen et al., 2001) and Antarctica (Petit et al., 1999; Wolff et al., 2010), terrestrial pollen records (Tzedakis et al., 1997; Reille et al., 1998), deep ocean records (Bassinot et al., 1994; Van Gijsel, 2006), Chinese speleothem records (Cheng et al., 2009) and the Baikal Lake records (Prokopenko et al., 2006, 2010). According to Meijs (2002) the five loess beds A to E and their intercalated luvisols can be correlated with these global 100 ka glacial-interglacial cycles. Besides the motives given by Meijs (2002), the principal lines of argument can be summarised as follows:

- Each individual loess bed, A to E, contains indisputable relics of frost-action processes (pellet sands and large ice-wedge casts, both indicators of permafrost; Meijs, 2011).

- The successive loess beds differ with respect to their heavy mineral composition (Meijs, 2002; Pirson, 2007).

- The dust curves from the Greenland and Antarctica ice records indicate that loess accumulation mainly occurred during glacials and scarcely during cold episodes within interglacials (Petit et al., 1999; Lambert et al., 2008). Although sometimes extremely cold, oscillations during interglacials were clearly too short for loess accumulation on any major scale.

- The red-brown luvisols intercalated between each of these loess beds provide distinct evidence of interglacial soil formation (i.e. macroscopically and/or micromorphologically demonstrated by the presence of massive non-humic clay illuviation; Mees, 1984; Van Vliet-Lanoë, 1986; Antoine, 2002; Schirmer, 2002).
In addition, numerous authors have demonstrated that various European river terrace sequences follow the same glacialinterglacial cycle of approximately $100 \mathrm{ka}$ (Kukla, 1975; Bibus, 1980; Felder \& Bosch, 1989; Van den Berg, 1996; Antoine et al., 1998; Schirmer, 2002; Meijs, 2002; Van Gijsel, 2006; Penkman et al., 2007). Besides faulting and sudden uplift, this $100 \mathrm{ka}$ cycle indeed acts as the main driver of fluvial terrace formation, with gravel aggradation occurring more or less contemporaneously with loess deposition, that is, during the cold glacials. The relation between the nomenclature used for the ocean records, the geology and the archaeology in relation to their absolute age is shown in Table 1.

Table 1. Geological and archaeological classification in relation to the Marine Isotope Stages and their chronology.

\begin{tabular}{llll}
\hline $\begin{array}{l}\text { Marine Isotope } \\
\text { Stage (MIS) }\end{array}$ & & $\begin{array}{l}\text { Chronology } \\
\text { (ka) }\end{array}$ & Archaeology \\
\hline MIS 1 & Holocene & Present-12 & \\
MIS 2 & Late Pleistocene & $12-30$ & Upper Palaeolithic \\
MIS 3-5 & & $30-130$ & Middle Palaeolithic \\
MIS 6-8 & Middle Pleistocene & $130-280$ & \\
MIS 9-19 & & $280-800$ & Lower Palaeolithic \\
\hline
\end{tabular}

\section{Chronostratigraphic interpretation of the Maas record}

Across Europe, from eastern England (Meijer \& Preece, 2000; Penkman et al., 2007), northern France (Antoine et al., 1998; Antoine, 2002; Antoine et al., 2003; Bahain et al., 2007; Antoine et al., 2010), central Belgium (Tuffreau \& Antoine, 1995; Haesaerts \& Mestdagh, 2000), western Germany (Bibus, 1980; Schirmer 1999, 2000, 2002), Serbia (Markovic et al., 2009) to the Czech Republic (Kukla, 1975), regional river terrace sequences and loess records show an essentially uniform picture, with aggradation of river gravels and sands and accumulation of loess occurring during glacial periods, and luvisol formation and deposition of fine-grained river sediment (overbank loam) during interglacials. The overall chronostratigraphic correlation of the loess beds and river terraces in the study area with the global climate record of the past 650 ka previously reported in Meijs (2002) has here been adjusted for part of the Maas terrace sequence (Fig. 11). Here the Maas river terrace sequence shows several clear chronostratigraphic markers. Thus, the gravel beds of the Pietersberg-2 and Pietersberg- 3 terraces were deposited just before the Brunhes-Matuyama palaeomagnetic reversal around 800-850 ka ago (MIS 22 and MIS 20, Table 2; Van den Berg, 1996). The terrace levels of Belvédère (MIS 8; Van Kolfschoten et al., 1993; Losson et al., 2001; Cordier et al., 2006) and Maasmechelen/Maarland (MIS 2-4; Paulissen, 1973) also provide robuust markers (Table 2). The latter forms the highest terrace level containing the volcanic minerals of the Rocourt tephra, deriving from an eruption at the beginning of MIS 4, while mineralogy studies show that the capture of the Maas by the 
Moselle near Toul took place at the end of the gravel aggradation phase of the Belvédère terrace (Krook, 1993). Given the terrace sequences observed in other European river basins, between MIS 20 and MIS 8 the Maas could have formed five river terraces (Van Gijsel, 2006). In this region four river terraces are present between the Pietersberg-2 and the Belvédère level (Fig. 4; Table 2). Only the Vroenhoven terrace exhibits an oblique gravel base, probably because of continuing incision in the outer bend of an ancient river meander. Here the height-difference between the basal gravel of the Vroenhoven and Belvédère terraces is around 15 metres, while elsewhere successive terraces differ by around 7 metres. It is therefore anticipated that there will be another river terrace between the Vroenhoven and Belvédère level. After Van den Berg (1996) this will most probably be the river terrace of Caberg-2. In the study area there is evidence of accelerated uplift during MIS 9/10 and MIS 17/18 (Van Gijsel, 2006), which would have caused more pronounced downcutting of the Belvédère and Hazendans river terraces (Table 2). Considering this fact, the distance between the gravel bases of the Caberg-2 and Belvédère terrace will be greater than that between the Caberg-2 and Vroenhoven terrace. In the former Belvédère pit the actual thickness of the Belvédère terrace gravels is up to around 10 metres, probably as a result of intensified gravel aggradation in MIS 8 after the accelerated uplift in MIS 9/10. Based on these data the gravel base of the Caberg-2 terrace is estimated to be 59 metres +OL (Table 2).

In general the glacial to interglacial transition is very abrupt (Petit et al., 1999; Johnsen et al., 2001; Van Gijsel, 2006; Wolff et al., 2010). Compared with the overall glacial period, moreover, climatic conditions towards the end of a glacial are extremely arid (Reille et al, 1998; Tzedakis et al, 2007). During the extended transitional periods from interglacial to glacial conditions (30-40 thousand years), the rivers had plenty of time to incise deep into the underlying terrace, with their beds later being infilled with river gravel and coarse sands during the ensuing glacial: the gravel aggradation phase. In these long transitional phases climatic conditions fluctuated widely, moreover, and it was during such fluctuations that downcutting was most pronounced. Both the continental Baikal Lake climate curve and the Antarctica and deep ocean records show a very protracted and irregular transition from MIS 9 to MIS 8 (Petit et al., 1999; Prokopenko et al., 2006; Van Gijsel, 2006; Wolff et al, 2010). Taken together with the accelerated uplift, these conditions could indeed have led to the deep down-cutting of the Belvédère river terrace (Table 2). As mentioned before the Belvédère terrace gravels in the former Belvédère pit are up to around 10 metres thick, moreover, providing further support for the terrace correlation proposed in Table 2.

To avoid confusion, several terrace stages that have been stratigraphically combined in this paper or published previously under a different name and/or age have been assigned a new name and relative age (Table 2).

\section{Chronostratigraphic interpretation of the loess record}

The loess sequence in this region provides an excellent highresolution terrestrial archive of climate forcing, showing cycles of landscape stabilisation and soil formation, erosion, cryogenic activity and deposition of loess and slope-derived sediments. It

Table 2. Maas terraces in the study area: gravel heights and proposed new chronostratigraphic correlation and nomenclature.

\begin{tabular}{|c|c|c|c|c|c|c|}
\hline Terrace name & $\begin{array}{l}\text { Felder \& Bosch, } \\
1989\end{array}$ & $\begin{array}{l}\text { Van den Berg, } \\
1996\end{array}$ & $\begin{array}{l}\text { Gravel height } \\
\text { (this paper) }\end{array}$ & & $\begin{array}{l}\text { Terrace name } \\
\text { (this paper) }\end{array}$ & $\begin{array}{l}\text { Chronostratigraphy } \\
\text { (this paper) }\end{array}$ \\
\hline $\begin{array}{l}\text { Gravel heights near } \\
\text { Maastricht }\end{array}$ & $\begin{array}{l}\text { Gravel base } \\
(\mathrm{m}+0 \mathrm{~L})\end{array}$ & $\begin{array}{l}\text { Gravel top } \\
(\mathrm{m}+0 \mathrm{~L})\end{array}$ & $\begin{array}{l}\text { Gravel base } \\
(\mathrm{m}+0 \mathrm{~L})\end{array}$ & $\begin{array}{l}\text { Gravel top } \\
(\mathrm{m}+0 \mathrm{~L})\end{array}$ & & \\
\hline Maasmechelen/Maarland & 39.3 & 51.3 (MIS 2-4) & & & Maasmechelen/Maarland & MIS 2-4 (A-loess) \\
\hline Eisden-Lanklaar/Gronsveld & 44.3 & 54.3 (MIS 6) & & & Eisden-Lanklaar/Gronsveld & MIS $6 \quad$ (B-loess) \\
\hline Caberg & 49.3 & & 49 & 59 & Belvédère & MIS 8 (C-loess) \\
\hline Caberg-3 & & 59.3 (MIS 8) & & & & \\
\hline Caberg-2 & & 65.3 (MIS 10) & 59 (estimate) & 65.3 & $\begin{array}{l}\text { Caberg-2 (not present } \\
\text { in this area) }\end{array}$ & MIS 10 (D-loess) \\
\hline Caberg-1 & & 72.3 (MIS 12) & 64 & 72 & $\begin{array}{l}\text { Vroenhoven (= Rothem-2; } \\
\text { Felder \& Bosch, 1989) }\end{array}$ & MIS 12 (E-loess) \\
\hline Rothem-2 & 67.3 & 78.3 (MIS 14) & 72 & 78 & $\begin{array}{l}\text { Kesselt (= Rothem-1; } \\
\text { Felder \& Bosch, 1989) }\end{array}$ & MIS 14 \\
\hline Rothem-1 & 72.3 & 83.8 (MIS 16) & 78 & 87 & Hazendans & MIS 16 \\
\hline Gravenvoeren (Van den Berg) & & 88.3 (MIS 18) & & & & \\
\hline Gravenvoeren (Felder \& Bosch) & 87.3 & & 88 & 92 & Dousberg & MIS 18 \\
\hline Pietersberg-3 & & 99.8 (MIS 20) & & & $\begin{array}{l}\text { Pietersberg-3 (not present } \\
\text { in this area) }\end{array}$ & MIS 20 \\
\hline Pietersberg-2 & 97.3 & 106.8 (MIS 22) & 97 & & Pietersberg-2 & MIS 22 \\
\hline
\end{tabular}




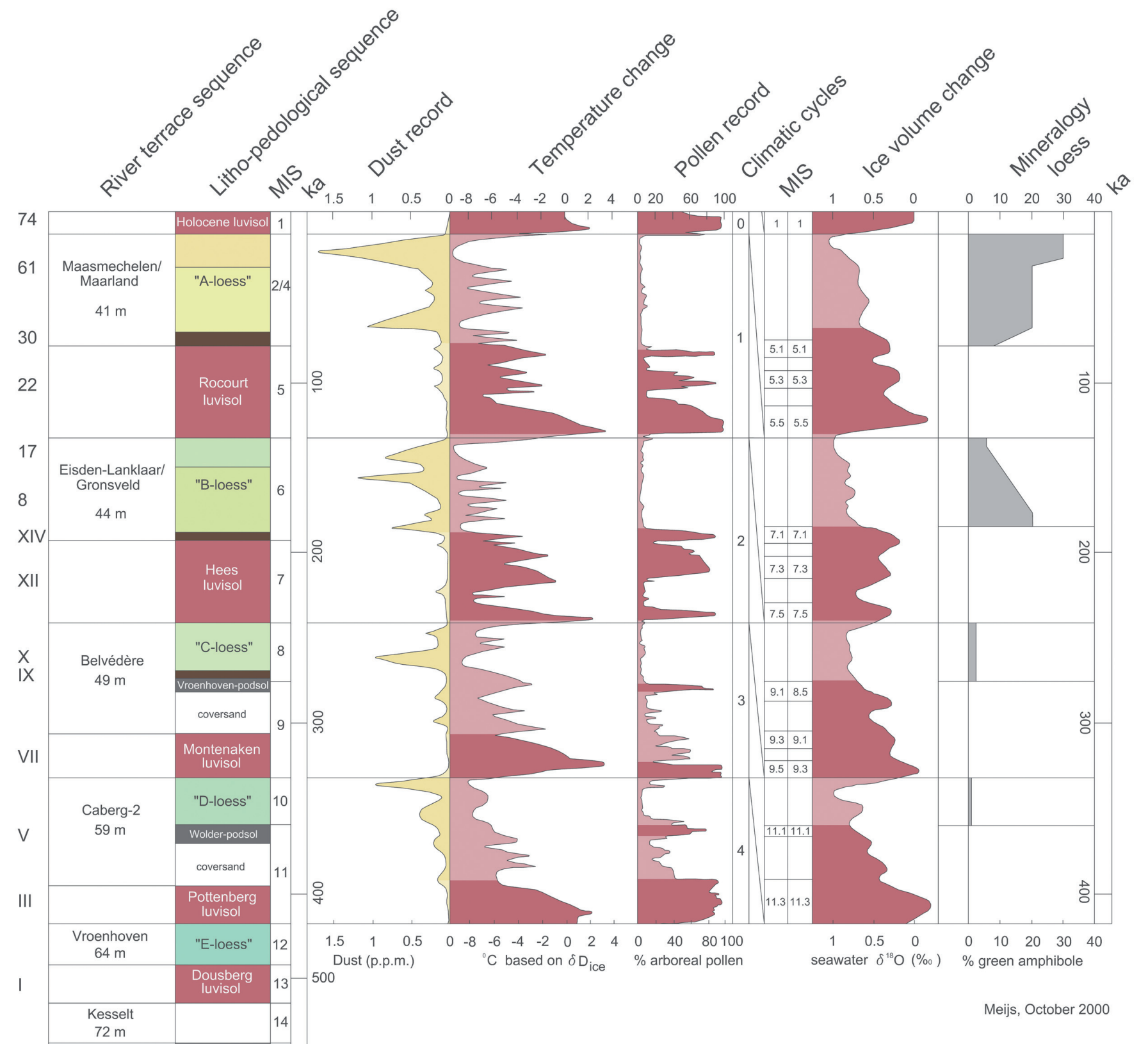

Fig. 11. Chronostratigraphic correlation of loess beds and river terraces in the study area with the global climate, dust, pollen and ocean records, after Petit et al. (1999), Reille et al. (1998) and Bassinot et al. (1994).

has been compared with other loess sequences across Europe and the unambiguous picture to emerge is of polygenetic luvisols (or soil complexes) being formed during interglacials, alternating with deposition of thick loess stacks during glacials. The interglacial palaeosols are sometimes intercalated with loess deposits, which are generally no more than 1 metre thick and exhibit no signs of cryogenic activity (Schirmer, 2002). These shallower loess beds are consequently not considered to reflect true glacials (Schirmer, 2002). Complementing the Maas terrace record, the loess sequence provides a second set of distinct chronostratigraphic markers, in the first place the characteristic MIS 2 deflation horizon ('patina discordance') and the Rocourt tephra signature from the beginning of MIS 4
(Frechen et al., 2001; Meijs, 2011; unit 61 and 31 respectively, Fig 5). In addition, units $8 \mathrm{a}-8 \mathrm{e}$ are possibly equivalent to the 'Bruchköbeler Nassböden' of MIS 6 age (Fig. 5; Bibus, 1980; Meijs, $2002,2011)$. It is assumed that the extraordinary well developed purplish-red marbled Pottenberg soil was formed during the long-lasting and relatively continuous interglacial period of MIS 11 (Prokopenko et al., 2010). Together, this suggests that between the MIS 11 and MIS 6 units two interglacial palaeosols (MIS 9 and MIS 7) intercalated with loess from the glacials MIS 10 and MIS 8 should be present. In the chronostratigraphic model elaborated for this region these are provided, respectively, by the Montenaken luvisol and Hees luvisol and the D-loess and C-loess (Fig. 11; see also Meijs, 2002). As set out earlier this 
correlation is hypothetical, but strongly supported by both (micro)morphological studies of luvisols and the periglacial processes evidenced in the intercalated loess sediments.

\section{Archaeology of the 0p de Schans site level 5}

\section{Introduction}

During the 2007 excavations to explore two of the four Middle Palaeolithic concentrations at level 3 of the $0 p$ de Schans loess pit, almost four metres deeper, at level 5, a locus with Lower Palaeolithic artefacts was discovered. Four south-north oriented exploratory trenches had been dug, each extending about three to four metres down from the level 3 Middle Palaeolithic excavation surface. In places two interglacial luvisols were exposed, separated by a body of loess (Fig. 3 and 7). In the west of the pit three trenches had been dug in line with one another (Fig. 12 and 13; Van Baelen et al., 2008), along with a shorter trench to the east (Fig. 12 and 14).

\section{The Lower Palaeolithic locus in the eastern trench}

In 2007 a Lower Palaeolithic locus (Fig. 3, level 5) was discovered in the eastern trench by De Warrimont. The artefacts recovered, a large bifacial side-scraper (Fig. 15) and an atypical biface (Fig. 16), were found in sediment removed by the mechanical digger from the deepest, southernmost part. This sediment had been deposited in a longitudinal heap along the trench. The artefacts were found in a patch of light-coloured, whitish sandy sediment containing a certain amount of Maas gravel, which

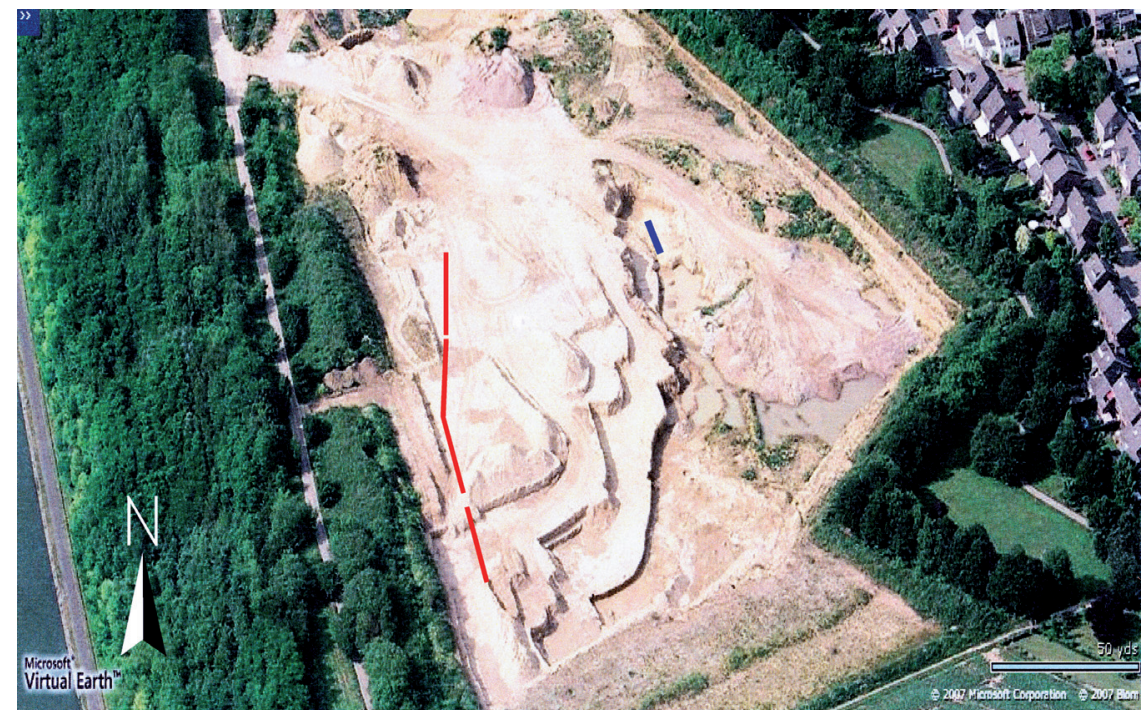

Fig. 12. Satellite view (2007) of the southern part of the Op de Schans pit; to the west (bottom left) the Albert Canal and to the east Daalhof, a housing estate at the edge of Maastricht. The eastern trench is marked by the blue rectangle, the western trenches are marked in red. Source: Microsoft Virtual Earth ${ }^{\mathrm{TM}}$.

Fig. 13. The middle of the three trenches in the west of the Op de Schans pit, viewed from the north. At the top of the profile, above the light-coloured aeolian coversand (1), the archaeological level 3 (MIS 9/8) is present. The two interglacial luvisols, the (upper) red-brown Montenaken soil (2) and (lower) purplish-red marbled Pottenberg soil (5), are separated by a greyish-yellow band of D-loess (3). On top of the Pottenberg soil an erosion horizon with coarse gravel can be discerned: the Pottenberg discordance (4). See Fig. 3, 7 and 12 for stratigraphic overview and location.

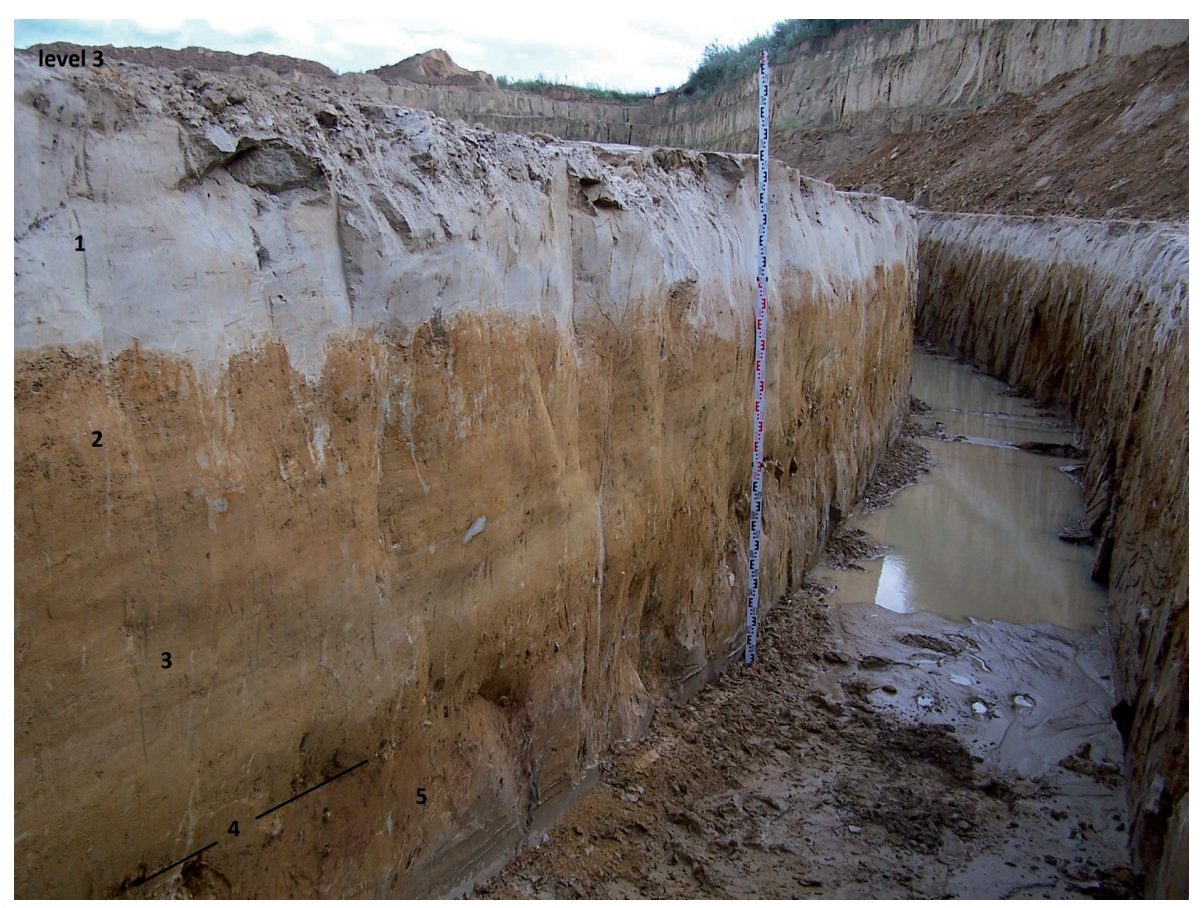




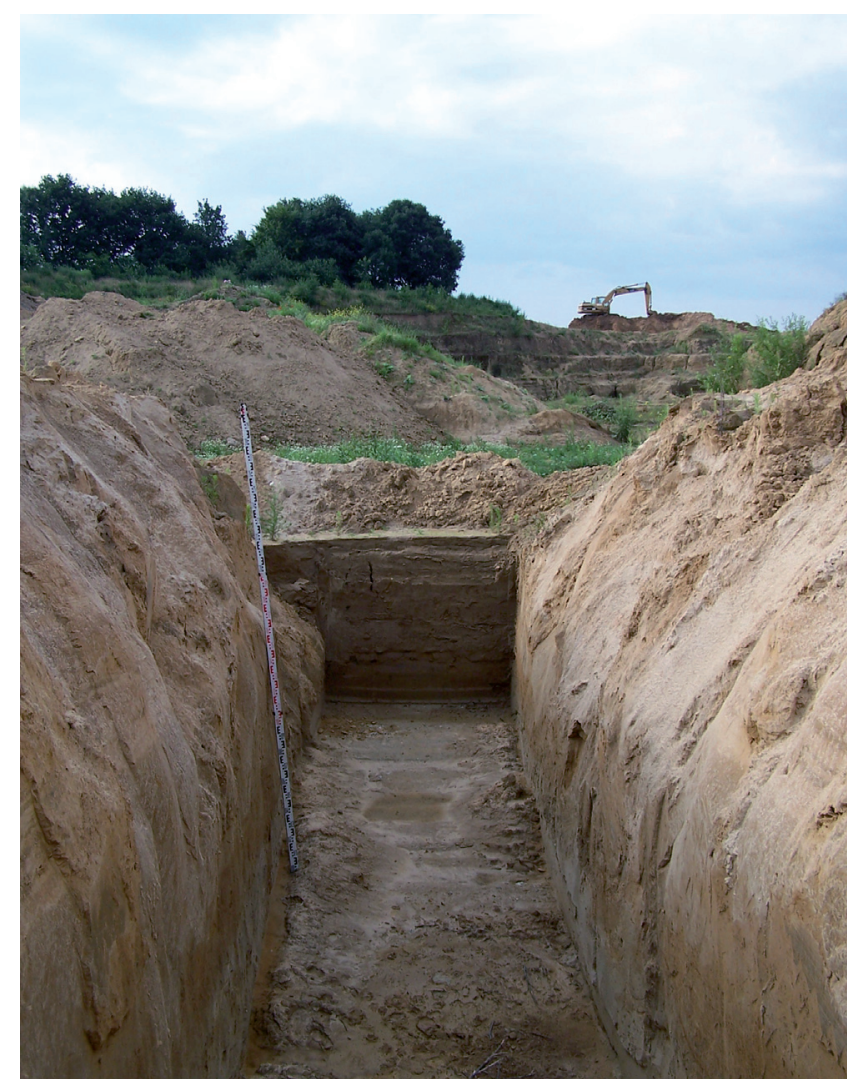

Fig. 14. The eastern trench in the Op de Schans pit, viewed from the north. The gravel-containing whitish sand layer was excavated near the base of the measuring rod to find in situ artefacts (for location see Fig. 12). Photo: Jean Pierre de Warrimont. was noticeably rich in rolled white quartz pebbles. Observation revealed this sediment originated from the deepest southernmost part of the trench (Fig. 14). The bifacial side-scraper has a maximum length of $129 \mathrm{~mm}$, is $85 \mathrm{~mm}$ wide and $29 \mathrm{~mm}$ thick. It has a brown patina, gloss and worn edges, is heavily eroded and has a frost crack on its dorsal face. It also has a pot-lid 9 $\mathrm{mm}$ in diameter, further evidence of frost damage. It is made of so-called Lanaye flint, which is common in this region, inter alia in the Maas terrace gravels. On several parts of the surface are numerous small black spots, interpreted as being Fe/Mnconcretions. The dorsal face has been heavily retouched, although there is still a patch of cortex present. The ventral face is also retouched in several places. It has a robust butt and a distinct percussion bulb. The atypical biface is $103 \mathrm{~mm}$ long, $56 \mathrm{~mm}$ wide and $26 \mathrm{~mm}$ thick. On the dorsal face there is still cortex present and both faces have local Fe/Mn-concretions. This bifacially worked artefact is also made from Lanaye flint and with its brown colouring, gloss and worn state shows great similarity to the bifacial sidescraper.

\section{Archaeological excavation}

Following detection of the probable archaeological level 5, a rescue dig was initiated in the southernmost part of the 4 metre deep trench with the aim of recovering any in situ artefacts in the gravel-containing whitish sand layer (Fig. 14; for a lithological description: see Table 3). On this spot a small test 'trenchlet' (Fig. 17, right) was dug down through the top of the gravel-containing whitish sand layer. Here, this layer is $40 \mathrm{~cm}$ thick and in places contains dark-green, oval, rounded lumps of
Fig. 15. Bifacial sidescraper, found on the side of the eastern trench; left: dorsal face, right: ventral face. Photos: Jean Pierre de Warrimont.
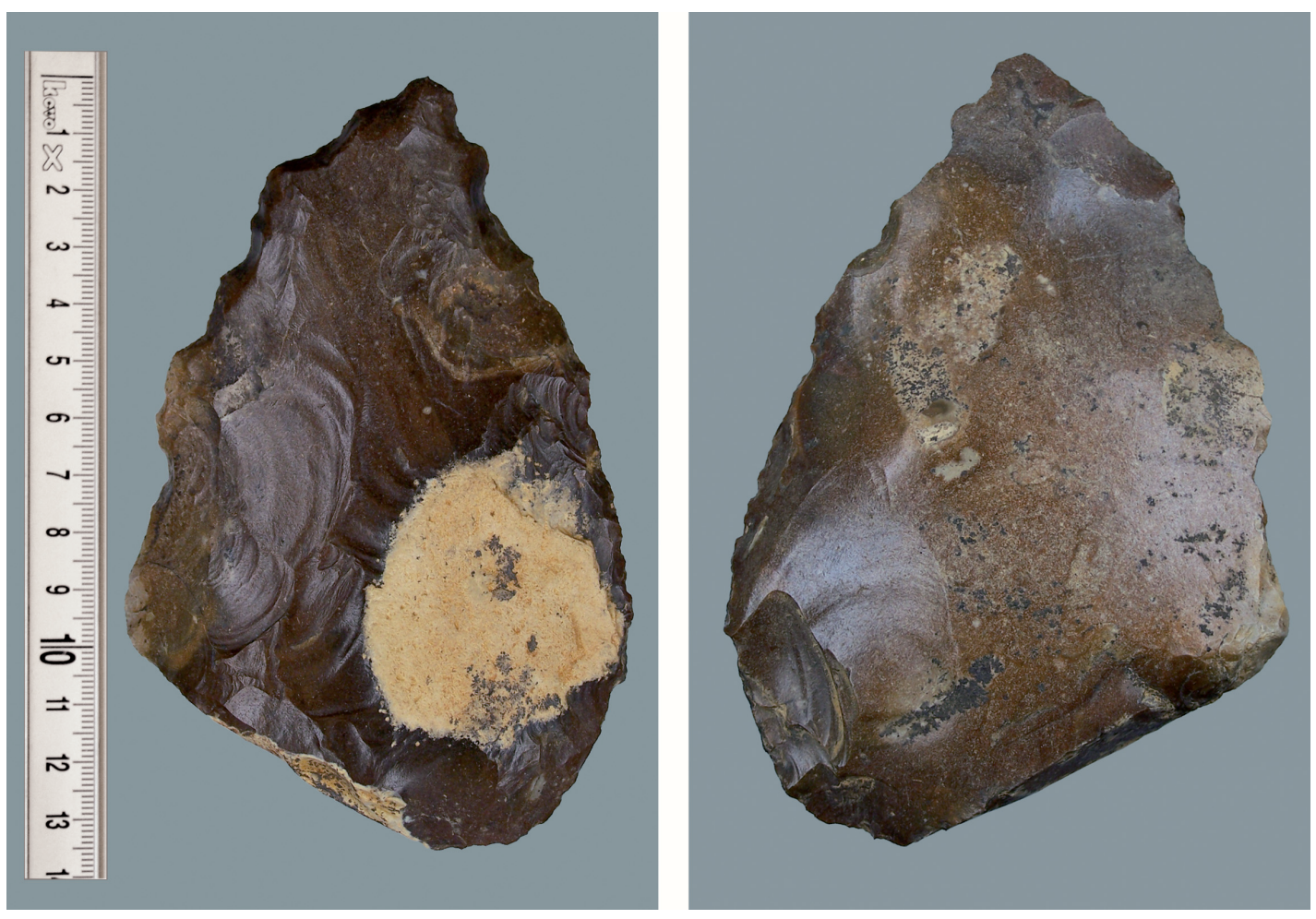

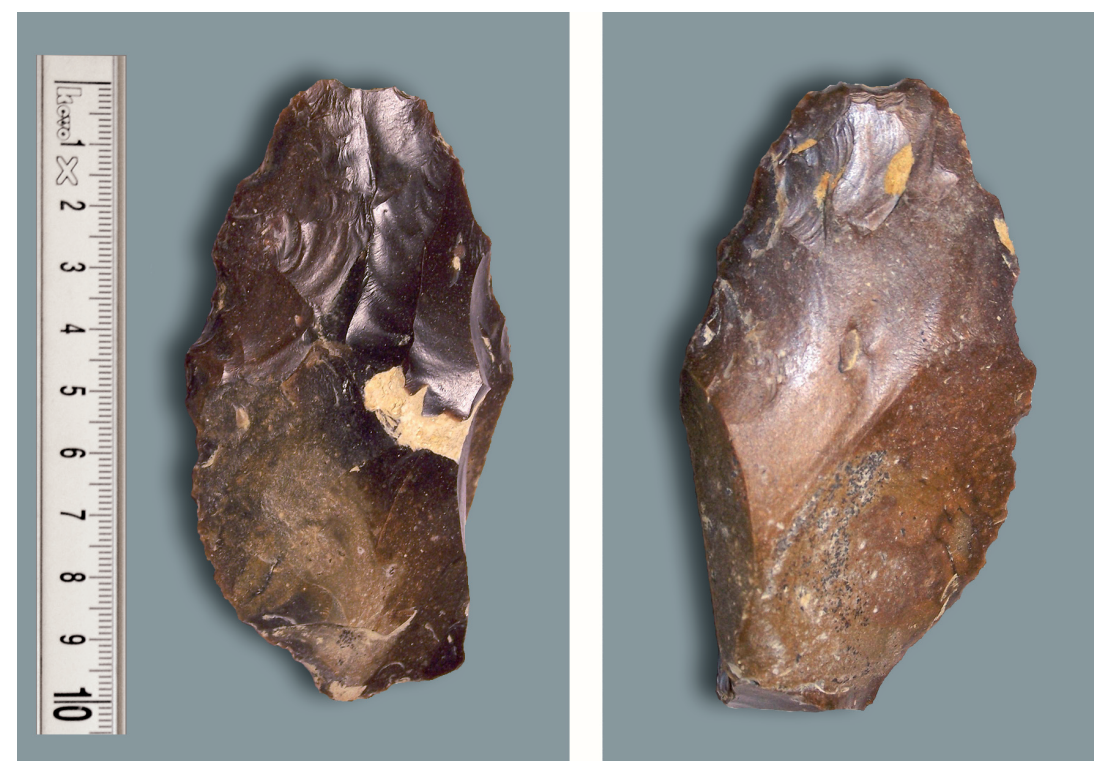

Fig. 16. Atypical biface found in the sediment adjacent to the eastern trench; left: dorsal face, right: ventral face. Photos: Jean Pierre de Warrimont.

loam and clay (probably transported in a frozen state by melt water and only thawing post-sedimentation). The upper half contains coarse gravel (maximum size: $30 \mathrm{~cm}$ in diameter). Deeper in the profile the sand is loamier, greener in colour and exhibits finer gravel, but in diminishing quantity. Most of the cobbles are rolled and severely eroded, some of them even partly disintegrated (excluding the quartzes and quartzites). Many of the angular flints in this gravel had been shattered by frost action. In the exposed horizontal surface, up to $5 \mathrm{~cm}$ wide, light or dark coloured bands were observed that appeared to be relic ice-wedge polygons. The exposed surface of the putative archaeological level 5 was then systematically excavated. During this excavation of approximately $4 \mathrm{~m}^{2}$ not a single convincing artefact was found, however. After this initial exploration the weather changed and a period of heavy rain set in, resulting in a waterlogged situation that prevented further excavation. It was therefore decided to use a mechanical digger to extend the trench by $30 \mathrm{~m}^{2}$ and deposit the excavated sediment, containing the putative archaeological horizon, on a dry spot to the south-west of the trench, so it could later be scrutinised for any artefacts.

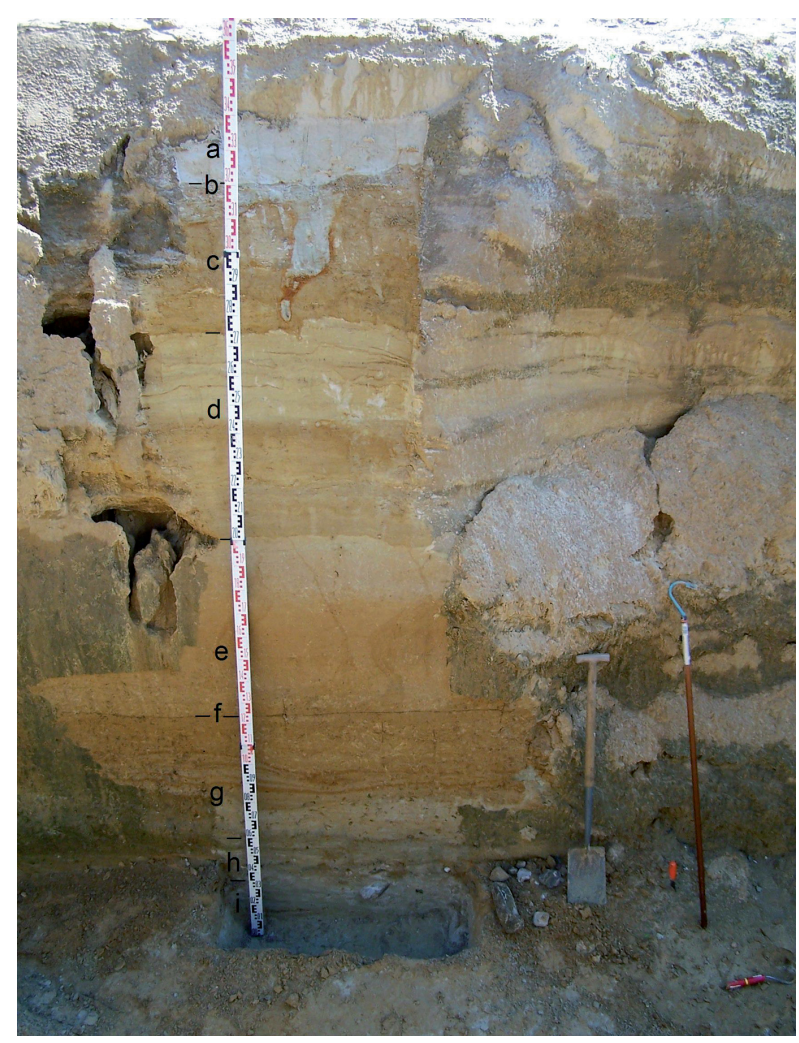

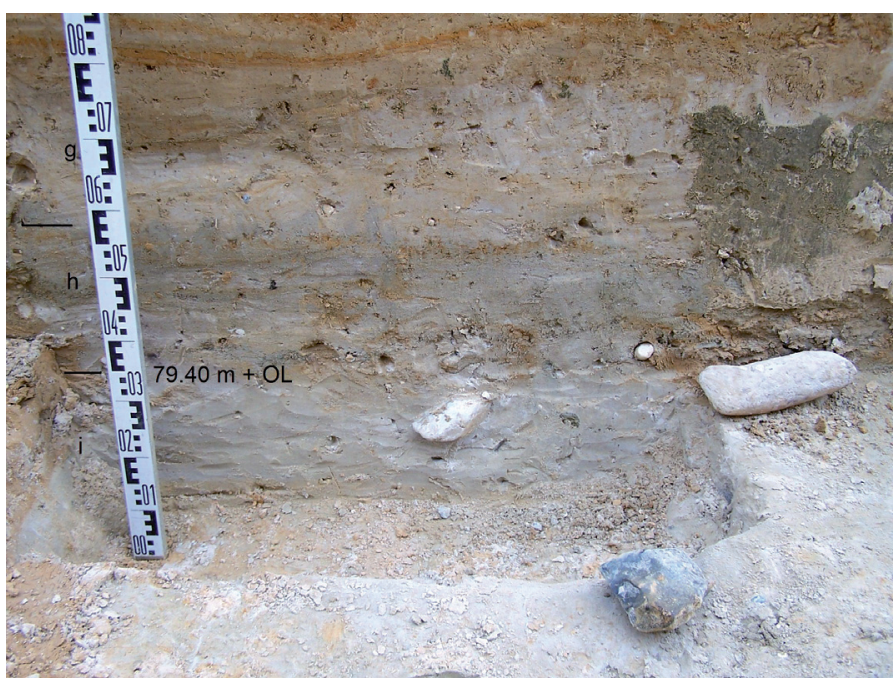

Fig. 17. The east wall of the eastern trench. Left: the almost 4 metre high profile with at its base the whitish gravel-containing sand. Right: close-up of the 'trenchlet'; here the whitish gravel-containing sand is overlain by stratified sediment containing clay and loam. For a detailed description of the sediment units see Table 3. Photos: Jean Pierre de Warrimont. 
Fig. 18. Dorsal and ventral face of the cortical flake excavated from the gravel-containing whitish sand at the bottom of the 4 metre deep eastern trench. Photos: Jean Pierre de Warrimont.
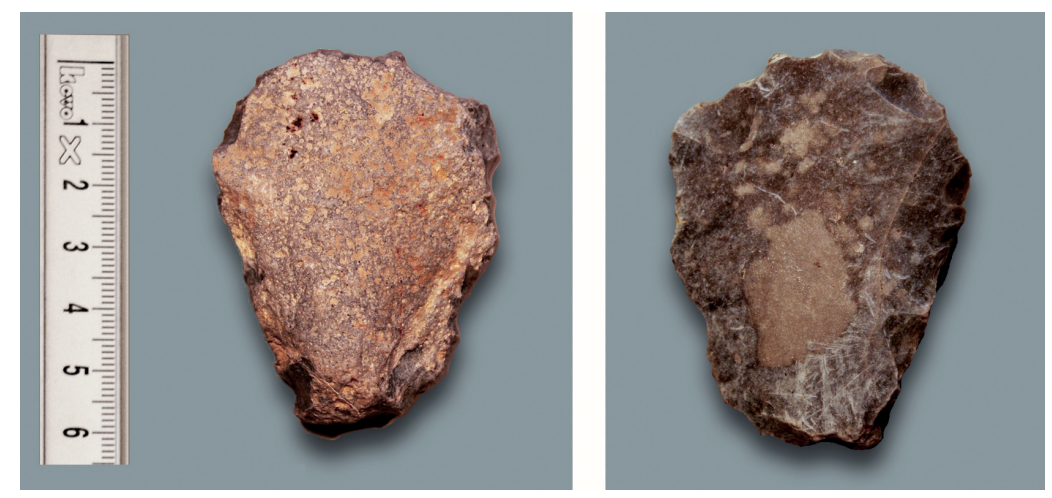

The portion remaining in the trench could still be examined in situ. The horizon in question could be seen to peter out towards the north and the east. This was interpreted as being the edge of a former gully. Of the surface remaining in situ only $2 \mathrm{~m}^{2}$ could be examined. During this in situ exploration an artefact was found: a $61 \mathrm{~mm}$ long, $47 \mathrm{~mm}$ wide and $16 \mathrm{~mm}$ thick severely worn grey cortical flake with a percussion bulb (Fig. 18). A frost crack is present on the ventral surface of this artefact. Based on the features of the percussion bulb, butt, the percussion angle and the ventral face, this was deemed to be an artefact. The flake was recovered from the top $10 \mathrm{~cm}$ of the gravel-containing whitish sands at the base of the vertical profile shown in Fig. 17, where the milky quartzes can be seen in the photo.

Subsequently, a pit was dug in the bottom of the eastern trench extending up to 1 metre down from the $40 \mathrm{~cm}$ thick whitish sands. The aim was to track down the underlying Maas terrace level. The top of the Maas loam was indeed reached, but not the sandy terrace gravels. The gravel-containing whitish sand that had been excavated and deposited alongside the trench was also carefully examined for artefacts. Although no artefacts were recovered, a thick, brown, patinated piece of Lanaye flint (length: $51 \mathrm{~mm}$, width: $63 \mathrm{~mm}$, thickness: $26 \mathrm{~mm}$ ) emerged with a percussion bulb and with a colour and gloss very similar to those of the bifacial side-scraper. Its surface was also characterised by the same Fe/Mn concretions. Given the gravel-containing context it was interpreted as an incertofact rather than an artefact.

Extending down from the laminated reworked loam (unit $\mathrm{g}$ ) a relic ice-wedge network is present, with casts around $10 \mathrm{~cm}$ wide. Higher up, these fade into indistinct frost cracks that are truncated horizontally by erosion at $2.75 \mathrm{~m}$.

Fig. 19. The infill sediments of the ancient erosion gully on top of the (unexposed) underlying Kesselt Maas terrace deposits. At the base of this profile a gravel layer is present, which is interpreted as being the bottom of the Pottenberg discordance (top Maas loam - base Pottenberg discordance). Photo: Jean Pierre de Warrimont.
Table 3. Lithological units of the eastern trench profile (Fig. 17).

\begin{tabular}{|c|c|c|}
\hline Unit & Heights (m) & Description \\
\hline $\mathrm{a}$ & $3.20-4.00$ & $\begin{array}{l}\text { Homogeneous greyish-yellow to whitish aeolian } \\
\text { coversand, with an average thickness of } 80 \mathrm{~cm} \text {. } \\
\text { On top of this coversand archaeological level } 3 \text { is } \\
\text { present (not exposed here) }\end{array}$ \\
\hline $\mathrm{b}$ & 3.20 & $\begin{array}{l}\text { Base of the homogeneous greyish-yellow to } \\
\text { whitish aeolian coversand }\end{array}$ \\
\hline c & $2.75-3.20$ & $\begin{array}{l}\text { Truncated, pseudogleyed, brown-coloured } \\
\text { interglacial luvisol (Montenaken soil) }\end{array}$ \\
\hline d & $2.00-2.75$ & $\begin{array}{l}\text { Stratified grey to yellow loam and sand } \\
\text { (sesquioxide-rich) }\end{array}$ \\
\hline e & $1.24-2.00$ & $\begin{array}{l}\text { Homogeneous greyish sandy loess with small } \\
\text { white mottles (D-loess) }\end{array}$ \\
\hline $\mathrm{f}$ & 1.24 & $\begin{array}{l}\text { Gravel veneer with scattered gravels max. } 2 \mathrm{~cm} \\
\text { in diameter }\end{array}$ \\
\hline g & $0.58-1.24$ & $\begin{array}{l}\text { Stratified brown and grey loam (with horizontal } \\
\text { ferruginous bands) }\end{array}$ \\
\hline $\mathrm{h}$ & $0.35-0.58$ & Stratified grey clay containing fine gravels \\
\hline $\mathrm{i}$ & $0-0.35$ & $\begin{array}{l}\text { Stratified gravel-containing whitish sands, with } \\
\text { an artefact between } 0.25 \text { and } 0.35 \mathrm{~m} \\
\text { (archaeological level 5) }\end{array}$ \\
\hline
\end{tabular}

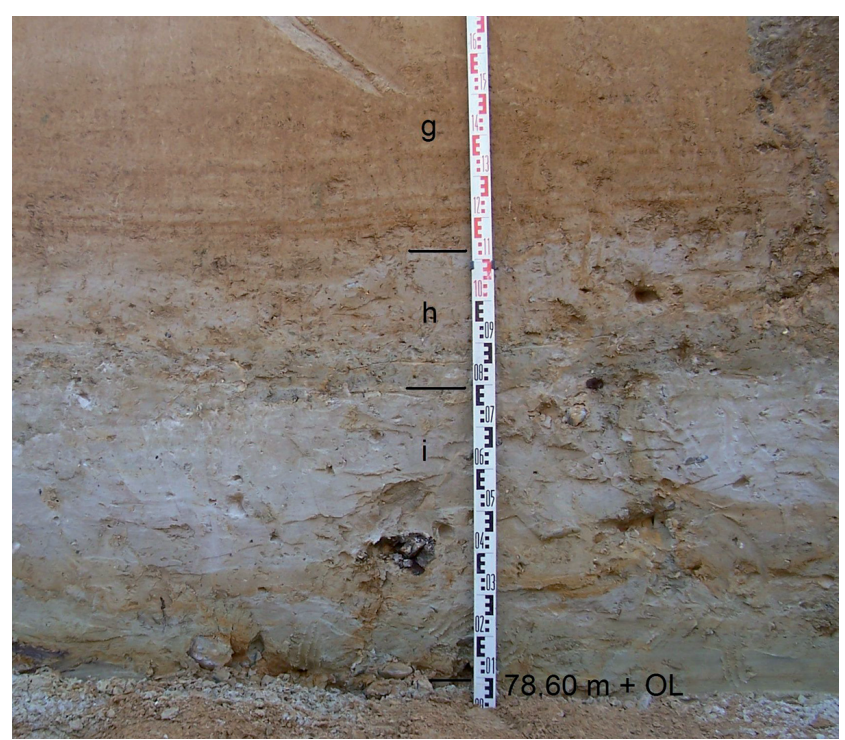




\section{Stratigraphic position of the finds}

It cannot be excluded that the gully in which the level 5 artefacts were found belongs to the Dousberg discordance and that the gravel veneer at $1.24 \mathrm{~m}$ (Fig. 17, unit f) represents the Pottenberg discordance (see question mark in Fig. 3). This would make the level 5 archaeological horizon one interglacialglacial cycle older. Favouring this interpretation are the ferruginous bands in the stratified brown and grey coloured loam (Fig. 17, unit g) beneath this gravel veneer, which may have formed by soil formation processes. This Pottenberg soil would then have been removed later by the erosion associated with the gravel layer at $1.24 \mathrm{~m}$. On the other hand, these ferruginous bands could also have been formed by the Wolder podsol formation above the Pottenberg discordance. Besides, similar ferruginous phenomena are also observed at the transition to relic (pseudo-)water tables. Given that the underlying Maas loam here is clayey and compact, the presence of fossil groundwater would seem plausible. In favour of a Pottenberg gully is the deeper incision depth of the Pottenberg erosion and the presence of considerably more and larger gravels in the Pottenberg discordance than those observed in the erosion line at $1.24 \mathrm{~m}$ (with a maximum diameter of $2 \mathrm{~cm}$ ). These arguments, as well as the occurrence of redeposited artefacts in the same discordance outside the gully (Fig. 3 and 7, level 4), make it likely that the level 5 artefacts are an equivalent of the Pottenberg erosion phase.

The described artefacts were probably carried in along the gully from an uphill part of the adjacent landscape. The composition of the sediment from which they derive and the eroded nature of the artefacts are strong evidence that the artefacts have been redeposited, implying that they are potentially older than the gully infill itself. The dimensions of the artefacts and cobbles from the gully sediment indicate that the discharge rate of the (melt)water must have been considerable. The conclusion is that the artefacts were not recovered from their primary archaeological context. After the artefacts had been deposited in the gravel-containing whitish sands they were frost-shattered. A relic ice-wedge network extends down from the stratified loamy gully infill through the archaeological horizon of level 5. In the middle of the western trenches, too, a deep, D-loess-filled ice-wedge network was encountered. Here the ice-wedge casts penetrate all the way through the Pottenberg discordance and Pottenberg soil into the underlying stratum (Fig. 7). The cold permafrost period evidenced could be an equivalent of the intense cold that occurred during and after deposition of the artefacts in the more eastern gully.

The chronostratigraphic position of the archaeological level 5 stratigraphically overlying the Pottenberg soil, is thus most probably the beginning of MIS 10 (approx. 390 ka; Prokopenko et al., 2010), however it cannot be entirely excluded that the erosion gully from which the artefacts derive dates from an early phase of MIS 12 (approx. $480 \mathrm{ka}$ ), given that the decisive profile could not be exposed (as indicated by the question mark in Fig. 3). The deeper Pottenberg incision known from various locations in this region and the occurrence of redeposited artefacts in the Pottenberg discordance outside the gully, (more south-westerly in the 0p de Schans pit; level 4 in Fig. 3 and 7), argue for a chronostratigraphic position at around the start of MIS 10 (approx. $390 \mathrm{ka}$, during the era of the Pottenberg discordance). The absolute age may in fact be greater, however, as the artefacts have been eroded from their original position (primary context) and subsequently deposited on the Pottenberg discordance. Hypothetically, they could even derive from the Maas loams of the Kesselt Maas terrace (MIS 13). In that case, the maximum age of the level 5 artefacts recovered from the gully would be approximately $500 \mathrm{ka}$ (MIS 13).

In terms of typology, these flint tools can be classified as Acheulean. Neither the artefacts from this archaeological locus (level 5) nor those from the gravel of the Pottenberg discordance elsewhere in the pit (level 4), show any signs of Levallois technology being used. This contrasts with all the artefacts recovered from younger, Middle Pleistocene sediments in this pit and the surrounding area, including the MIS $9 / 8$ concentrations from the $0 p$ de Schans pit (level 3, Van Baelen et al., 2008) and the two MIS 7 levels in the Belvédère pit, which show a (proto-)Levallois technology (De Warrimont, 2007). The Acheulean, characterised by a high proportion of bifacial tools, is possibly already present in north-west Europe in MIS 15, but certainly in MIS 13 and later (Antoine et al., 2010; Hosfield, 2011). In this part of Europe there are no well-dated Acheulean sites that have been dated to beyond 500-550 ka (Hosfield, 2011).

The various lines of evidence suggest that the artefacts discussed in this paper have a likely minimum age of approx. $400 \mathrm{ka}$ and a maximum age around $500 \mathrm{ka}$. This is within the same range as finds from the high terraces of the Haine Valley in southern Belgium, where Lower Palaeolithic sites yielding Acheulean artefacts have been described by Tuffreau \& Antoine (1995) at Pa d'la l'iau (MIS 12, with Acheulean artefacts) and Petit-Spiennes (MIS 10, with Acheulean artefacts and Levallois cores and flakes).

\section{Conclusions}

The oldest artefacts (level 5) in a gully in the 0p de Schans pit probably date from a period after formation of the Pottenberg soil and coincide with the era of the Pottenberg discordance. This gully may also have been formed at the time of the Dousberg discordance, some 100,000 years earlier. The incision depth of the gully and the nearby presence of redeposited artefacts in the Pottenberg discordance outside the gully (level 4), indicate that the level 5 sediments were probably deposited at the beginning of MIS 10. As the artefacts have been redeposited, their original age might be greater. Based on 
the chronostratigraphic model developed for this region, the sediments in which the oldest artefacts from the 0p de Schans pit were found were deposited approximately 390,000 years ago. Typologically, they can be classed as Acheulean artefacts, which on the basis of the chronostratigraphy can be assigned to the Lower Palaeolithic (Table 1). They were recovered from a secondary context. The assumed minimum age of the artefacts is around $400 \mathrm{ka}$, with a possible maximum of around $500 \mathrm{ka}$.

\section{Acknowledgements}

We are very grateful to pit owners Vandersanden N.V. for their kind cooperation and to Nigel Harle for his careful translation of the Dutch text and helpful comments on several issues. We would also like to thank Max Klasberg, who helped with the excavations, Tim Vanderbeken (Zuid-0ost-Limburgse Archeologische Dienst; ZOLAD+) and Ann Van Baelen for their kind cooperation.

\section{Notes}

1 The archaeological site was originally referred to as 'Veldwezelt - 0p de Schans' (Vroomans et al., 2006), but has since been renamed 'Kesselt - 0p de Schans'. The loess pit in question is designated as '0p de Schans' and is situated in the parish of Kesselt (in the former municipality of Veldwezelt), which is now part of the amalgamated municipality of Lanaken (B). The pit has two sections: a northern section that was operated from 2000 to 2003 and an adjacent southern section operated from 2003 to 2009. The two sections are contiguous and are located between the Albert Canal and the BelgianDutch border to the west of Maastricht.

The brickyard pit containing the archaeological site of Veldwezelt-Hezerwater (likewise in the former municipality of Veldwezelt), is referred to as 'Veldwezelt'.

2 As described by Vroomans et al. (2006), the chronostratigraphic position of level 1-south is uncertain (MIS 3 or older). Here it is assumed this archaeological level has the same stratigraphic position as level 1-north.

3 Following the stratigraphical revision by Juvigné et al. (1996), the luvisol termed the 'Rocourt soil' in the micromorphological study of Mees (1984) is here referred to as the 'Hees soil' (Meijs, 2002).

\section{References}

Antoine, P., Lautridou, J.-P., Sommé, J., Auguste, P., Auffret, J.-P., Baize, S., Clet-Pellerin, M., Coutard, J.-P., Dewolf, Y., Dugué, O., Joly, F., Laignel, B.,

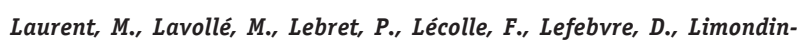
Lozouet, N., Munaut, A.-V., Ozouf, J.-C., Quesnel, F. \& Rousseau, D.-D., 1998. Les formations quaternaires de la France du Nord-Ouest: limites et corrélations. Quaternaire 9: 227-241.

Antoine, $\boldsymbol{P}$., 2002. Les loess en France et dans le Nord-Ouest européen. Revue française de Géotechnique 99: 3-21.
Antoine, P., Auguste, P., Bahain, J.-J., Coudret, P., Depaepe, P., Fagnart, J.-P., Falguères, C., Fontugne, M., Frechen, M., Hatté, C., Lamotte, A., Laurent, M., Limondin-Lozouet, N., Locht, J.-L., Mercier, N., Moigne, A.-M., Munaut, A.V., Ponel, P. \& Rousseau, D.-D., 2003. Paléoenvironnements pléistocènes et peuplements paléolithiques dans le bassin de la Somme (nord de la France). Bulletin de la Société préhistorique française 100: 5-28.

Antoine, P., Rousseau, D.-D., Moine, 0., Kunesch, S., Hatté, C., Lang, A., Tissoux, H. \& Zöller, L., 2009. Rapid and cyclic aeolian deposition during the Last Glacial in European loess: a high-resolution record from Nussloch, Germany. Quaternary Science Reviews 28: 1-19.

Antoine, P., Auguste, P., Bahain, J.-J., Chaussé, C., Falguères, Ch., Ghaleb, B., Limondin-Lozouet, N., Locht, J.-L. \& Voinchet, P., 2010. Chronostratigraphy and Palaeoenvironments of Acheulean occupations in Northern France (Somme, Seine and Yonne valleys). Quaternary International 223-224: 456-461.

Bahain, J.-J., Falguères, C., Laurent, M., Voinchet, P., Dolo, J.-M., Antoine, P. \& Tuffreau, A., 2007. ESR chronology of the Somme river terrace system and first human settlements in northern France. Quaternary Geochronology 2: 356-362.

Bassinot, F. C., Labeyrie, L. D., Vincent, E., Quidelleur, X., Shackleton, N. J. \& Lancelot, Y., 1994. The astronomical theory of climate and the age of the Brunhes-Matuyama magnetic reversal. Earth and Planetary Science Letters 126: 91-108.

Bibus, E., 1980. Zur Relief-, Boden- und Sedimententwicklung am unteren Mittelrhein. Frankfurter Geowissenschaftliche Arbeiten D1, Frankfurt am Main: $295 \mathrm{pp}$.

Bringmans, P.M.M.A., 2006. Multiple Middle Palaeolithic occupations in a Loesssoil sequence at Veldwezelt-Hezerwater, Limburg, Belgium. Katholieke Universiteit Leuven, unpublished PhD thesis.

Cheng, H., Lawrence Edwards, R., Broecker, W.S., Denton, G.H., Kong, X., Wang, Y., Zhang, R. \& Wang, X., 2009. Ice age terminations. Science 326: 248-252.

Cofflet, L. \& Schirmer, W., 2002. Paleomagnetic investigations in Erkelenz and Rheindahlen. In: Loess units and soil complexes in the Niederrhein and Maas area. Terra Nostra 1: 51-56.

Cordier S., Harmand, D., Frechen, M. \& Beiner M., 2006. Fluvial system response to Middle and Upper Pleistocene climate change in the Meurthe and Moselle valleys (Eastern Paris Basin and Rhenish Massif). Quaternary Science Reviews 25: 1460-1474.

Cordy, J.-M. \& Udrescu, M., 1999. Etude préliminaire des restes paléontologiques découverts en 1999 à la carriere Nelissen à Kesselt. Université de Liege, Département de l'Évolution des Vertébrés et Évolution humaine (Liège), 2 pp.

Demek, J. \& Kukla, J., 1969. Periglazialzone, Löss und Paläolithicum der Tschechoslowakei. Tschechoslowakische Akademie der Wissenschaften, Geografisches Institut (Brno): 1-158.

De Warrimont, J.P.L.M.N., 2007. Prospecting Middle Palaeolithic open-air sites in the Dutch-Belgian border area near Maastricht. PalArch's Journal of Archaeology of Northwest Europe 1, 3: 40-89.

Felder, W.M. \& Bosch, P.W., 1988. Geologische kaart van Zuid-Limburg en omgeving, Oppervlaktekaart. Geologische Dienst Heerlen. Rijks Geologische Dienst Heerlen.

Felder, W.M. \& Bosch, P.W., 1989. Geologische kaart van Zuid-Limburg en omgeving, Afzettingen van de Maas. Rijks Geologische Dienst Heerlen. 
Frechen, M., Van Vliet-Lanoë, B. \& Van den Haute, P., 2001. The Upper Pleistocene loess record at Harmignies/Belgium - high resolution terrestrial archive of climate forcing. Palaeogeography, Palaeoclimatology, Palaeoecology 173: 175-195.

Geolab, 1996. Boringen ten behoeve van ontginningszone Kesselt voor Gewestplan Limburgs Maasland, gemeente Lanaken, kaartblad 34/2, Geolab b. v.b.a. Boringen-Bodemonderzoek, Plaanstraat 1, 9810 Eke-Nazareth, Belgium.

Haesaerts, P. \& Van Vliet-Lanoë, B., 1973. Évolution d'un permafrost fossile dans les limons du Dernier Glaciaire à Harmignies (Belgique). Bulletin de l'Association française pour l'Étude du Quaternaire 35: 151-164.

Haesaerts, P. \& Van Vliet-Lanoë, B., 1981. Phénomènes périglaciaires et sols fossiles observés à Maisières-Canal, à Harmignies et à Rocourt. Biuletyn Peryglacjalny 28: 291-324.

Haesaerts, P. \& Mestdagh, H., 2000. Pedosedimentary evolution of the last interglacial and early glacial sequence in the European loess belt from Belgium to central Russia. Geologie en Mijnbouw 79: 313-324.

Halet, F., 1932. La Géologie du flanc occidental de la vallée de la Meuse à l'Ouest de l'enclave de Maastricht d'après les sondages d'étude du Canal Albert. Bulletin de la Société belge de Géologie 42: 195-225.

Hosfield, R., 2011. The British Lower Palaeolithic of the early Middle Pleistocene. Quaternary Science Reviews 30: 1486-1510.

Huijzer, A.S., 1993. Cryogenic microfabrics and macrostructures: interrelations, processes and paleoenvironmental significance. Thesis Vrije Universiteit Amsterdam: $245 \mathrm{pp}$.

Johnsen, S.J., Dahl-Jensen, D., Gundestrup, N., Steffensen, J.P., Clausen, H.B., Miller, H., Masson-Delmotte, V., Sveinbjörnsdottir, A.E. \& White, J., 2001. 0xygen isotope and paleotemperature records from six Greenland ice-core stations: Camp Century, Dye-3, GRIP, GISP2, Renland and NorthGRIP. Journal of Quaternary Science 16: 299-307.

Juvigné, E., Haesaerts, P., Mestdagh, H., Pissart, A. \& Balescu, S., 1996. Révision du stratotype loessique de Kesselt (Limbourg, Belgique). Comptes rendus de l'Académie de Sciences de Paris 323: 801-807.

Krook, L., 1993. Heavy minerals in the Belvédère deposits. In: Vandenberghe, J., Roebroeks, W. \& Van Kolfschoten, T. (eds): Maastricht-Belvédère: stratigraphy, palaeoenvironment and archaeology of the Middle and Late Pleistocene deposits Part II. Mededelingen Rijks Geologische Dienst 47: 25-30.

Kuijper, W.J., 2003. Internal report Saalian molluscs in Veldwezelt pit. Leiden: 1-2. Kukla G.J., 1975. Loess stratigraphy of Central Europe. In: Butzer, K. W. \& Isaac, G.L. (eds): After the Australopithecines: stratigraphy, ecology, and culture change in the Middle Pleistocene. Mouton (The Hague/Paris): pp. 99-188.

Lambert, F., Delmonte, B., Petit, J.R., Bigler, M., Kaufmann, P.R., Hutterli, M.A., Stocker, T.F., Ruth, U., Steffensen, J.P. \& Maggi, V., 2008. Dust-climate couplings over the past 800,000 years from the EPICA Dome $C$ ice core. Nature 452: 616-619.

Lauwers R. \& Meijs E.P.M., 1985. Ein Mittelpaläolithischer Fundplatz in Kesselt (Prov. Limburg, Belgien), Erste Ergebnisse. Archäologisches Korrespondenzblatt 15, Heft 2: 123-129.

Losson B. \& Quinif Y., 2001. The Moselle piracy, new chronological data from U/Th dating of speleothems. Karstologia 37: 29-40.

Markovic, S.B., Hambach, U., Catto, N., Jovanovic, M., Buggle, B., Machalett, B., Zöller, L., Glaser, B. \& Frechen, M., 2009. Middle and Late Pleistocene loess sequences at Batajnica, Vojvodina, Serbia. Quaternary International 198: 255-266.
Mees, R.P.R., 1984. Paleobodems in de löss in West- en Midden-Europa. Doctoral thesis, Instituut voor Bodemkunde, Rijksuniversiteit Utrecht: 72 pp.

Mees, R.P.R. \& Meijs, E.P.M., 1984. Note on the presence of pre-Weichselian loess deposits along the Albert Canal near Kesselt and Vroenhoven (Belgian Limbourg). Geologie en Mijnbouw 63: 7-11.

Meijer, T. \& Preece, R.C., 2000. A review of the occurrence of Corbicula in the Pleistocene of North-West Europe. Geologie en Mijnbouw / Netherlands Journal of Geosciences, 79 (2/3): 241-255.

Meijs, E.P.M., 2002. Loess stratigraphy in Dutch and Belgian Limburg. Eiszeitalter und Gegenwart 51: 114-130.

Meijs, E.P.M., 2006. Paleolithic and Quaternary research in the European loess belt (www.archeogeolab.nl).

Meijs, E.P.M., 2011. The Veldwezelt site (province of Limburg, Belgium), environmental and stratigraphical interpretations. In: Jagt, J.W.M., JagtYazykova, E.A. \& Schins, W.J.H. (eds): A tribute to the late Felder brothers pioneers of Limburg geology and archaeology. Netherlands Journal of Geosciences 90 (2-3): 73-94.

Moine, 0., 2010. Report on the malacofaunas of Saalian loess from Kesselt (Belgium). Laboratoire de Géographie Physique, Meudon (France): 12 pp.

Paulissen, E., 1973. De morfologie en de kwartairstratigrafie van de Maasvallei in Belgisch Limburg. Verhandelingen van de Koninklijke Academie voor Wetenschappen, Letteren en Schone Kunsten van België 35: 127 pp.

Petit, J.R., Jouzel, J., Raynaud, D., Barkov, N.I., Barnola, J.-M., Basile, I., Benders, M., Chappellaz, J., Davis, M., Delaygue, G., Delmotte, M., Kotlyakov, V.M., Legrand, M., Lipenkov, V.Y., Lorius, C., Pépin, L., Ritz, C., Saltzman, E. \& Stievenard, M., 1999. Climate and atmospheric history of the past 420,000 years from the Vostok ice core, Antarctica. Nature 399: 429-436.

Pirson, S., 2007. Contribution à l'étude des dépôts d'entrée de grotte en Belgique au Pléistocène supérieur; stratigraphie, sédimentogenèse et paléoenvironnement. Université de Liège (Liège) (unpublished $\mathrm{PhD}$ thesis): $435 \mathrm{pp}$.

Penkman, K.E.H., Preece, R.C., Keen, D.H., Maddy, D., Schreve, D.C. \& Collins, M.J., 2007. Testing the aminostratigraphy of fluvial archives, the evidence from intra-crystalline proteins within freshwater shells. Quaternary Science Reviews 26: 2958-2969.

Prokopenko, A.A., Hinnov, L.A., Williams, D.F. \& Kuzmin, M.I., 2006. Orbital forcing of continental climate during the Pleistocene: a complete astronomically tuned climatic record from Lake Baikal, SE Siberia. Quaternary Science Review 25: 3431-3457.

Prokopenko, A.A., Bezrukova, E.V., Khursevich, G.K., Solotchina, E.P., Kuzmin, M.I. \& Tarasov, P.E., 2010. Climate in continental interior Asia during the longest interglacial of the past 500000 years: the new MIS 11 records from Lake Baikal, SE Siberia. Climate of the Past 6: 31-48.

Reille, M., Andrieu, V., de Beaulieu, J.-L, Guenet, P. \& Goeury, C., 1998. A long pollen record from Lac du Bouchet, Massif Central, France: for the period ca. 325 to $100 \mathrm{ka}$ (0IS 9c to 0IS 5e). Quarternary Science Reviews 17: 1107-1123.

Roebroeks, W., 1988. From Find Scatters to Early Hominid Behaviour. A Study of Middle Palaeolithic Riverside Settlements at Maastricht-Belvédère (the Netherlands), Leiden (= Analecta Praehistorica Leidensia 21).

Schirmer, W., 1999. Kaltzeiten und Warmzeiten im Löss. In: Becker-Haumann, R. \& Frenchen, M. (eds): Terrestrische Quartärgeologie (Köln): 81-100.

Schirmer, W., 2000. Eine Klimakurve des Oberpleistozäns aus dem rheinischen Löss. Eiszeitalter und Gegenwart 50: 25-49. 
Schirmer, W., 2002. Compendium of the Rhein loess sequence. In: Ikinger, A. \& Schirmer, W. (eds): Loess units and solcomplexes in the Niederrhein and Maas area. Terra Nostra 1: 8-23.

Tuffreau, A. \& Antoine, $P$., 1995. The earliest occupation of Europe: Continental Northwestern Europe. In: Roebroeks, W. \& Van Kolfschoten, T. (eds): The earliest occupation of Europe: 147-163.

Tzedakis, P.C., Andrieu, V., De Beaulieu, J.-L., Crowhurst, S., Follieri, M., Hooghiemstra, H., Magri, D., Reille, M., Sadori, L., Shackleton, N.J. \& Wijmstra, T.A., 1997. Comparison of terrestrial and marine records of changing climate of the last 500000 years. Earth and Planetary Science Letters 150: 171-176.

Van Baelen, A., Meijs, E.P.M., Van Peer, Ph., De Warrimont, J.P. \& De Bie, M., 2007. An Early Middle Palaeolithic site at Kesselt - 0p de Schans (Belgian Limburg), Preliminary results. Notae Praehistoricae 27: 19-26.

Van Baelen, A., Meijs, E.P.M., Van Peer, Ph., De Warrimont, J.P. \& De Bie, M., 2008. The Early Middle Palaeolithic Site of Kesselt - 0p de Schans (Belgian Limburg), Excavation Campaign 2008. Notae Praehistoricae 28: 5-9.

Van Baelen, A., 2012. A contribution of high resolution data to the study of the Lower-Middle Palaeolithic transition. PhD thesis, Katholieke Universiteit Leuven (in preparation).

Van Kolfschoten, T., Roebroeks, W. \& Vandenberghe, J., 1993: The Middle and Late Pleistocene sedimentary and climatic sequence at Maastricht-Belvédère. In: Vandenberghe, J., Roebroeks, W. \& Van Kolfschoten, T. (eds): MaastrichtBelvédère: stratigraphy, palaeoenvironment and archaeology of the Middle and Late Pleistocene deposits Part II. Mededelingen Rijks Geologische Dienst 47: 81-91.

Van de Moortel, K., 2008. Een bijdrage tot het geochronologisch onderzoek met de luminescentiedateringsmethode van de midden-pleistocene loessafzettingen te Vroenhoven (Belgisch Limburg). Licentiate thesis, Ghent University, 114 pp.

Van den Berg, M.W., 1996. Fluvial sequences of the Maas, a 10 Ma record of neotectonics and climate change at various timescales. Thesis. University Wageningen: $181 \mathrm{pp}$.

Vandenberghe, J., 1993. River terrace development and its relation to climate: the Saalian Caberg terrace of the Maas river near Maastricht (the Netherlands). In: Vandenberghe, J., Roebroeks, W. \& Van Kolfschoten, T. (eds): MaastrichtBelvédère: stratigraphy, palaeoenvironment and archaeology of the Middle and Late Pleistocene deposits Part II. Mededelingen Rijks Geologische Dienst 47: 19-24.

Vandenberghe, J., Mommersteeg, H. \& Edelman, D., 1993. Lithogenesis and geomorphological processes of the Pleistocene deposits at MaastrichtBelvédère. In: Vandenberghe, J., Roebroeks, W. \& Van Kolfschoten, T. (eds): Maastricht-Belvédère: stratigraphy, palaeoenvironment and archaeology of the Middle and Late Pleistocene deposits Part II. Mededelingen Rijks Geologische Dienst 47: 7-18.

Vandenberghe, J., Roebroeks, W. \& Van Kolfschoten, T. (eds), 1993. MaastrichtBelvédère: stratigraphy, palaeoenvironment and archaeology of the Middle and Late Pleistocene deposits Part II. Mededelingen Rijks Geologische Dienst 47, $91 \mathrm{pp}$.

Vandenberghe, J., Huijzer, B., Mücher, H. \& Laan, W., 1998. Short climatic oscillations in a western European loess sequence (Kesselt, Belgium). Journal of Quaternary Science 13 (5): 471-485.
Van Gijssel, K., 2006. A continent-wide framework for local and regional stratigraphies. Thesis, Rijks Universiteit Leiden, 120 pp.

Van Vliet-Lanoë, B., 1985. Frost effects in soils. In: Boardman, J. (ed.): Quaternary Landscape Evolution. Wiley (London): 117-158.

Van Vliet-Lanoë, B., 1986. Le Pédocomplexe du dernier interglaciaire (de 125000 á 75000 BP): Variations de faciès et signification paléoclimatique du sud de la Pologne à l'ouest de la Bretagne. Bulletin de l'Association francaise pour l'étude du Quaternaire 25-26: 139-150.

Vroomans, J.-M., Gullentops F., Vanderbeken, T., Groenendijk, K. \& Van Peer, Ph., 2006. De Midden-Paleolithische vindplaats Veldwezelt-0p de Schans (Limburg): een voorlopig rapport. Anthropologica et Praehistorica 117: 5-12.

Wolff, E.W., Barbante C., Becagli, S., Bigler, M., Boutron, C.F., Castellano, E., de Angelis, M., Federer, U., Fischer, H., Fundel, F., Hansson, M., Hutterli, M., Jonsell, U., Karlin, T., Kaufmann, P., Lambert, F., Littot, G.C., Mulvaney, R., Röthlisberger, R., Ruth, U., Severi, M., Siggaard-Andersen M.L., Sime, L.C., Steffensen, J.P., Stocker T.F., Traversi, R., Twarloh, B., Udisti, R., Wagenbach, D. \& Wegner, A., 2010. Changes in environment over the last 800,000 years from chemical analysis of the EPICA Dome C ice core. Quaternary Science Reviews 29: 285-295. 